\title{
A Framework for Reviewing the Trade-offs between Renewable Energy, Food, Feed and Wood Production at a Local Level
}

Submitted: 6 May 2011

Paul J. Burgess ${ }^{a^{*}}$, Monica Rivas-Casado ${ }^{\mathrm{a}}$, Jerry Gavu $^{\mathrm{a}}$, Andrew Mead $^{\mathrm{b}}$, Tim Cockerill $^{\mathrm{c}}$

Richard Lord ${ }^{\mathrm{d}}$, Dan van der Horst ${ }^{\mathrm{e}}$, and David C. Howard ${ }^{\mathrm{f}}$

a Department of Environmental Science and Technology, Cranfield University, Cranfield, Bedfordshire, MK43 OAL, UK

b Life Sciences, University of Warwick, Wellesbourne, Warwick, CV35 9EF, UK

c Centre for Environmental Policy, Imperial College, London, SW7 2AZ, UK

d School of Science \& Engineering, Teesside University, Middlesbrough, Tees Valley, TS1 3BA, UK

e School of Geography, Earth and Environmental Sciences, University of Birmingham, Edgbaston, B15 2TT, UK

f Centre for Ecology \& Hydrology, Lancaster Environment Centre, Lancaster, LA1 4AP UK

* $\quad$ Corresponding author: E-mail: P.Burgess@ cranfield.ac.uk

Tel: +44 (0) 1234 750111; Fax: +44 (0) 1234752971

Full postal address: Building 42a, Cranfield University, Cranfield, Bedfordshire, MK43 0AL, UK

\begin{abstract}
High fuel prices and concerns about energy security and anthropogenic climate change are encouraging a transition towards a low carbon economy. Although energy policy is typically set at a national level, tools are needed for people to engage with energy policy at regional and local levels, and to guide decisions regarding land use, distributed generation and energy supply and demand. The aim of this paper is to develop a percapita approach to renewable energy demand and supply within a landscape and to illustrate the key trade-offs between renewable energy, food, feed and wood production. The chosen case study area (16000 ha) of Marston Vale, England is anticipated to have a population density midway between that for England and the UK. The daily per capita demand for energy for heat $(31 \mathrm{kWh})$, transport $(34 \mathrm{kWh})$ and electricity $(15$ $\mathrm{kWh}$ ) when combined ( $80 \mathrm{kWh}$ ) was seven-fold higher than the combined demand for food ( $2 \mathrm{kWh})$, animal feed ( $6 \mathrm{kWh})$, and wood ( $4 \mathrm{kWh})$. Using described algorithms, the combined potential energy supply from domestic wind and photovoltaic panels, solar heating, ground-source heat, and municipal waste was limited $\left(<10 \mathrm{kWh} \mathrm{p}^{-1} \mathrm{~d}^{-1}\right)$. Additional electricity could be generated from landfill gas and commercial wind turbines, but these have temporal implications. Using a geographical information system and the Yield-SAFE tree and crop yield model, the capacity to supply
\end{abstract}


bioethanol, biodiesel, and biomass, food, feed and wood was calculated and illustrated for three land-use scenarios. These scenarios highlight the limits on meeting energy demands for transport (33\%) and heat (53\%), even if all of the arable and grassland area was planted to a high yielding crop like wheat. The described framework therefore highlights the major constraints faced in meeting current UK energy demands from land-based renewable energy and the stark choices faced by decision makers.

Key words: energy, wind, food, wood, ecosystem, landscape.

\section{Introduction}

The United Kingdom (UK), as is the case for many countries, faces an energy challenge. Reduced availability of domestic fossil fuels, rising fossil fuel prices and the need to constrain greenhouse gas emissions means that the country must either reduce energy consumption and/or develop new domestic energy sources with lower carbon footprints such as renewable energy.

In 2000, the UK Government's renewable energy policy [1] was to increase the contribution of electricity supplied from renewables to 5\% by the end of 2003 to $10 \%$ in 2010, assuming acceptable consumer costs. More recently, the 2009 renewable energy directives set a target for the UK to achieve $15 \%$ of its energy consumption from renewable sources by 2020 [2]. It is considered that this could be achieved by supplying $31 \%$ of the electricity demand, $10 \%$ of the transport demand and $12 \%$ of the heat demand [2]. In 2008, only about $2.3 \%$ of the delivered energy supply in the UK came from renewable sources [3]. The proportion of electricity from renewable sources was $5.5 \%$, and the proportions of transport fuel and energy for other use including heat were about $1.4 \%$ each.

The development of renewable energy sources, especially the cultivation of energy crops, also has the potential to affect our national and global ecosystems and the services they provide. These benefits provided by ecosystems have been termed "ecosystem services" [4]. In some of the literature on ecosystem services, the focus is on semi-natural and natural systems [5], however elsewhere the focus is on the full 
range of ecosystems including agricultural and urban systems [4]. Within the context of the UK, virtually all ecosystems are heavily affected by mankind and therefore this paper uses the wider interpretation.

Authors have generally found it useful to categorise the services that humans get from ecosystems into four or five functional groups which typically include a production, regulating and cultural component (Table 1). In addition to these groups De Groot [5] highlights a "habitat" and a "carrier" category. He defines the carrier function as the provision of a "space and suitable substrate to support infrastructure associated with human activities" and gives examples of the capture of wind and solar energy and the food production from cultivated land. However as mentioned previously, in the context of the UK, it is useful to view agriculture as being an ecosystem in its own right, and therefore this paper considers agricultural food production to be a production rather than a carrier service.

The research described in this paper was undertaken as part of a one year pilot project entitled "Energyscapes and Ecosystems Services" which sought to describe and explain the effect of different renewable energy systems on ecosystem services. The aim of this paper is to develop a per capita approach to renewable energy demand and supply within a predefined geographical area and, through the use of scenarios, to illustrate some of the key trade-offs and synergies between the production of renewable energy (electricity, transport, and heat) and the production of three other commodities, namely, food, animal feed and wood.

Place Table 1 here.

\section{Methodology}

\subsection{Case study area}

The Marston Vale comprises 16094 ha to south and west of the county town of Bedford in southern England (Figure 1). The area is bordered by the Greensand Ridge in the south and a motorway (the M1) in the south-west. Census data from 2001 indicates there were 10646 households in the area, and assuming a mean of 2.4 people per household in 2009 [7], this equates to 25550 people. The area is also part of a "growth 
area" and therefore there has been government investment in transport infrastructure to support housing development, including a new town, called Wixams, close to the centre of the area. In total it is estimated that development consent has been given for another 10036 houses, which assuming the same number of people per household, would double the population to 49637. This higher population is equivalent of 0.32 ha per person (3.1 people per ha). This is intermediate between the mean values for England (3.9 people per ha) and the UK (2.5 people per ha), but higher than mean values for the European Union (1.2 people per ha) or the world ( 0.46 people per ha).

Insert Figure 1 here.

\subsection{Mapping land use}

A digital map of the area was developed within a geographical information system ARCGIS (ESRI Inc, 2009) using aerial photographs from June 2009 available from Google Earth (Google, 2010). The field digitisation was performed at a basic scale of 1: 5000 with a minimum mapping unit of 0.5 ha. The land use within each polygon in the GIS was also coded into one of 17 categories which fall into three classes (Table 2) (Figure 1a).

Place Table 2 here.

Using current land use as a foundation, an additional category of "Consented development" was also created. The existing polygons in the same areas were then subdivided into areas where development was consented or not (Figure 1b). Lastly in order to facilitate statistical analysis, the land use polygons were expressed as values within a grid of $100 \mathrm{~m}$ x $100 \mathrm{~m}$ pixels. Because only those squares which lay completely within the Marston Vale were selected, the area of pixel-based data (15565 ha) was 3\% smaller than the area of the Vale (16094 ha). Using the pixel-based data, agriculture occupied about $71 \%$ of the total area (Table 3) compared to a values of $75 \%$ for England and $77 \%$ for the UK [8].

The principal arable crops were wheat (27\%) and oilseed rape (OSR) (9\%), with smaller areas of barley (3\%) and other crops including field beans and peas (7\%); a significant 
area $(6 \%)$ was also considered "fallow". Grassland occupied $18 \%$ of the area, which is less than the average value for England (39\%) and the UK (52\%), as a result of high proportion of arable land. The other principal land use categories were woodlands $(8 \%)$, urban (8\%), other (9\%), water (2\%) and land-fill (2\%) and water (2\%) (Table 3). The inclusion of consented development is predicted to increase the area allocated to urban land from 8 to $12 \%$, resulting in a reduction of land in the grassland and other categories.

Insert Table 3 here.

\subsection{Determining energy demand}

A key issue in energy-environment studies is a choice of unit that people can relate to. Whilst national statistics may use million tonnes of oils equivalent or Gigajoules, it is arguable that a more "human-sized unit" [9] is the number of kilowatt hours per day per person $\left(\mathrm{kWh} \mathrm{d}^{-1} \mathrm{p}^{-1}\right)$. One $\mathrm{kWh}$ is equivalent to $3600 \mathrm{~kJ}$. In 2002, the average world citizen consumed the equivalent of $56 \mathrm{kWh} \mathrm{d}^{-1}$ [10]. In 2008, the primary annual UK energy use was $117 \mathrm{kWh} \mathrm{d}^{-1} \mathrm{p}^{-1}$, approximately twice the global average [3]. Because the conversion of energy sources like coal and gas to electricity is typically about $30 \%$ efficient, the delivered energy is substantially lower. In 2008, the mean delivered energy per person in the UK was equivalent to $80 \mathrm{kWh} \mathrm{d}^{-1}$ [3] (Table 4).

Within Marston Vale, domestic energy use (electricity, transport, and heat and other) was calculated using estimates of the number of households per ward, and the mean household energy consumption for the two local authorities covering the area [11] (Table 4). Electricity and heat energy use within commercial buildings was derived from the plan area of the 88 largest warehouses and offices in the Marston Vale and average benchmark values for fossil fuel and electricity use per unit area of the commercial buildings [12]. The energy related to freight transport in the Vale was derived from freight transport energy use for the two local authority areas on a proportional area basis. The energy use associated with arable and grassland production systems were derived from land use data, agricultural statistics, and life cycle assessment values reported by Williams et al. [13]. The derived value of $81 \mathrm{kWh} \mathrm{p}^{-1} \mathrm{~d}^{-}$

\footnotetext{
${ }^{1}$ for the Vale is similar to the mean value of $80 \mathrm{kWh} \mathrm{p}^{-1} \mathrm{~d}^{-1}$ for the UK (Table 4).
} 
Place Table 4 here.

Using the national values, the current demand was established for electricity (15 kWh p $\left.{ }^{1} \mathrm{~d}^{-1}\right)$, transport $\left(34 \mathrm{kWh} \mathrm{p}^{-1} \mathrm{~d}^{-1}\right)$ and heat and other uses $\left(31 \mathrm{kWh} \mathrm{p}^{-1} \mathrm{~d}^{-1}\right)$. As indicated earlier, the UK is seeking to achieve $15 \%$ of its energy consumption from renewable sources by 2020 [2], which would be equivalent to $31 \%$ of the electricity demand, $10 \%$ of the transport demand and $12 \%$ of the heat demand [2]. Applied to UK energy use in 2008 , this is equivalent to $4.6 \mathrm{kWh} \mathrm{p}^{-1} \mathrm{~d}^{-1}$ electricity, $3.4 \mathrm{kWh} \mathrm{p}^{-1} \mathrm{~d}^{-1}$ transport fuel, and $3.7 \mathrm{kWh} \mathrm{p}^{-1} \mathrm{~d}^{-1}$ of heat.

\subsection{Food demand}

In the UK, the mean level of food energy purchased (including eating out and alcohol), for people aged above seven years is about $2275 \mathrm{kcal}$ per person per day [15] (Table 5). Food energy requirements for humans equate conceptually most closely with estimates of metabolisable energy [16], which is the energy that can be delivered by food minus the energy used for digestion. This daily value, which is equivalent to $2.65 \mathrm{kWh}$ per person, included household wastage which was assumed to be about $10 \%$. Pimental and Pimental [17] in the United States considered a diet equivalent to $3533 \mathrm{kcal}$ (4.1 kWh p ${ }^{1} \mathrm{~d}^{-1}$ ), which was considered to be $1000 \mathrm{kcal}$ above what was needed. Alexandratos et al. [18] using values from national food accounts rather household usage, estimated that daily food use per person in industrial countries was equivalent to $3446 \mathrm{kcal}$ ( $4.0 \mathrm{kWh})$ in 1999-2001.

Insert Table 5 here.

The mean daily UK consumption of food products of $2.65 \mathrm{kWh}$ per person comprises $1.93 \mathrm{kWh}(73 \%)$ which is plant-based and $0.72 \mathrm{kWh}(27 \%)$ which is animal-based [15]. Values for the energy density of milk, eggs and meat, and conversion rates of grass and grain for milk, egg and meat production were derived from Williams et al [13]. Using these values, the production of the typical range of animal products consumed in the UK requires $2.84 \mathrm{kWh} \mathrm{p}^{-1} \mathrm{~d}^{-1}$ of grass and $2.80 \mathrm{kWh} \mathrm{p}^{-1} \mathrm{~d}^{-1}$ of other animal feed (5.64 
$\mathrm{kWh} \mathrm{p}^{-1} \mathrm{~d}^{-1}$ in total) (Fig 2). This represents three-quarters of a combined food and feed requirement of $7.57 \mathrm{kWh} \mathrm{p}^{-1} \mathrm{~d}^{-1}$.

\subsection{Wood demand}

In 2005, the apparent consumption of wood in the UK, primarily in the form of paper, was 44.7 million $\mathrm{m}^{3}$ wood raw material equivalent underbark [19]. Assuming a UK population of 61.4 million in 2008 [7], this is equivalent to $0.728 \mathrm{~m}^{3}$ per person per year. Assuming a mean dry density for temperate wood of $460 \mathrm{~kg} \mathrm{~m}^{-3}$ [20], marketable timber with a moisture content (wet basis) of $30 \%$ would have a density of $657 \mathrm{~kg} \mathrm{~m}^{-3}$. Assuming that wood with a moisture content of $30 \%$ has an energy value of $12.1 \mathrm{MJ} \mathrm{kg}^{-}$ ${ }^{1}$ [21], this is equivalent to $4.4 \mathrm{kWh} \mathrm{p}^{-1} \mathrm{~d}^{-1}$ (Figure 2).

Insert Figure 2 here.

\subsection{Collation of energy data}

The potential supply of energy within Marston Vale was determined using algorithms combining spatial information with values determined from the literature. The assumed energy from solar panels on domestic buildings was based on the number of households, an estimate of the area per house, and the assumption that one-eighth of the roof area could be used for solar panel installation (Table 6). A similar estimate was derived for commercial buildings. Estimates for electricity energy from wind were based on the potential number of wind turbine sites beyond specific buffers around urban, commercial and woodland areas, and estimates of electricity output for a specific type of wind turbine (Table 7).

It was assumed that domestic solar heating panels would be designed to meet the hot water requirement in July (Table 8). For ground-source heating, the assumption was that ground-source heating could supply $100 \%$ of the space heating in new domestic buildings (Table 8). Estimates were also made of the energy that could be generated from municipal waste (Table 9). There was no significant source of hydro-electricity in the area. At present the only significant renewable energy source used in the Vale is the use of landfill gas to generate electricity. The active landfill sites at Brogborough, 
L'Field Stewartby, and Elstow generated 254 GWh of electricity over 12 months in 2009/10 [34] (Table 10). However this energy is being generated from waste obtained from an area extending beyond the Marston Vale, and the level of landfill gas will decline over time. Therefore although the resource is important in the short- to medium-term it is not a long-term renewable energy source.

Insert Table 6 here.

Insert Table 7 here

Insert Table 8 here

Insert Table 9 here

Insert Table 10 here

\subsection{Crop and tree yields}

The map of land use in 2009, illustrated in Figure 1b, was used to derive the area planted to arable crops, grassland and woodland. For the purpose of this analysis, all of the woodland was assumed to consist of hardwood species. The arable land was assumed to be planted to one of four species: winter wheat, winter barley, winter oilseed rape, and field beans as a representative spring crop. Soils data from the National Soil Resources Institute were also used to derive the soil type (coarse, medium, fine) and soil depth $(100$ to $150 \mathrm{~cm})$ across the study area. A digital terrain map was also used to determine aspect and thereby the amount of solar radiation that a site would receive relative to a horizontal area. Using the soils data and a climate series of daily solar radiation, temperature and rainfall data from the area, estimates of the yield (dry matter basis) was made for each crop type using the daily time-step Yield-SAFE model [35]. Because the effect of aspect on yield was minimal, it was not considered in the full analysis. The dry matter yield for each crop, as calculated for a fine (e.g. clay) soil of $150 \mathrm{~cm}$ depth, is presented in Table 11. Although not used in the analysis reported in this paper, the Yield-SAFE model was also parameterised to give estimates of an equivalent annual yield from short rotation willow coppice, miscanthus, and softwood woodland. The estimated dry matter yield of $9.7 \mathrm{t} \mathrm{ha}^{-1}$ for miscanthus is similar to the mean dry matter yield of $9.6 \mathrm{t} \mathrm{ha}^{-1}$ reported by Ritcher et al. [36]. The dry matter yield of $8.2 \mathrm{t} \mathrm{ha}^{-1}$ for willow short rotation coppice (SRC) is broadly similar to the mean dry matter yield of $9.0 \mathrm{t} \mathrm{ha}^{-1}$ reported over two rotations from the UK SRC field trial network by Aylott et al. [37]. Typical moisture contents of arable crops, grass and wood, as reported in Table 11, were also derived from the literature to allow the 
calculation of a yield on a fresh weight basis. In each case, it was assumed that all of the grain, oilseed, or pulse component of each crop would be harvested. However the proportion of straw that could be harvested from wheat, barley, oilseed and beans was assumed to be $65 \%$. The remaining $35 \%$ would remain as stubble in the field.

The proportion of the total weight of the wheat grain that could be used to produce ethanol (29\%) and distiller grains (10\% moisture content) $(47 \%)$ were derived from Mortimer et al. [38]. Estimates of the proportion of the weight of the rapeseed crop that could be used to produce biodiesel (35\%) and rapemeal (55\%) were derived from Mortimer et al. [39]. The proportion of above-ground tree biomass harvested as timber and branches harvested was derived from values cited by Norman et al. [40].

Insert Table 11 here.

The net calorific value of crop and tree products at a specified moisture content $\left(H_{\mathrm{u}(\mathrm{w})}\right.$; $\left.\mathrm{MJ} \mathrm{kg}^{-1}\right)$ depends on their calorific content when dry $\left(H_{\mathrm{u}(\mathrm{wf})} ; \mathrm{MJ} \mathrm{kg}^{-1}\right)$ and their moisture content $(w ; \%)$ (Equation 1) [45].

$$
H_{\mathrm{u}(\mathrm{w})}=\left[H_{\mathrm{u}(\mathrm{wf})}(100-w)-2.44 w\right] / 100
$$

Values of the net calorific content of crop and tree products when dry were largely derived from Kaltschmitt et al. [21] and Fehrenbach et al. [42], and corrected for the specified moisture content using Equation 1. The calorific value of crops as human feed or animal feed is typically expressed in terms of their metabolisable energy. These values were largely derived from Noblet et al. [41] and McDonald et al. [43] corrected for the stated moisture content (Table 11). The proportion of the energy that can be obtained from a biomass source also depends on the conversion process. For this analysis it was assumed that heat could be obtained at a conversion efficiency of $80 \%$ and electricity could be obtained at a conversion efficiency of $30 \%$.

\subsection{Establishing three energy scenarios}

In order to examine the main interactions between the supply of renewable energy, food, feed and wood, three scenarios were proposed (Table 12). Scenario 1, a base-line scenario assuming consented development, sought to maximise renewable energy from 
non-biomass sources whilst maintaining current production of food, feed and wood. Scenario 2 includes the same non-biomass renewable energy sources as scenario 1, but although crop areas were assumed to remain the same, wheat and oilseed surplus to human food consumption were allocated to the production of transport fuel and animal feed, and the harvested straw of all crops was used for heat. Use of non-timber wood as a heating fuel was also assumed. Scenario 3 focused on growing wheat, a particularly high yielding crop, on the whole arable and grassland area. It was assumed that once the human crop food requirement was met, all of the additional wheat grain would be converted to bio-ethanol and all of the harvestable straw would be used for heat.

Insert Table 12 here.

\section{Results}

As described in the methodology, three scenarios were used to illustrate possible tradeoffs and synergies between the different sources of renewable energy, and food, feed and wood production.

\subsection{Scenario 1 with no biomass renewables}

The first scenario assumed that biomass would be used as food for humans, feed for animals (barley grain, barley straw, rape-meal, pulses, grass), and wood for timber. The 2020 target renewable electricity supply $\left(4.6 \mathrm{kWh} \mathrm{p}^{-1} \mathrm{~d}^{-1}\right)$ could be met with photovoltaic panels on $12.5 \%$ of all roofing, seven commercial wind turbines, and energy from waste (Figure 3a). If 98 commercial wind turbines were installed, then potential electricity supply would be $24.2 \mathrm{kWh} \mathrm{p}^{-1} \mathrm{~d}^{-1}$ (Figure $3 \mathrm{~b}$ ). Renewable heating targets $\left(3.7 \mathrm{kWh} \mathrm{p}^{-1} \mathrm{~d}^{-1}\right)$ could be met from ground-source heat on all new buildings. Current human food supply was predicted to exceed demand due to the high production of wheat grain (Figure 3). In practice much of this wheat might be allocated to animal feed, primarily for pigs and poultry. There is a short-fall in wood supply and no supply of transport fuel.

Insert Fig 3 here.

\subsection{Scenario 2 Current cropping with biomass renewables}

Assuming current cropping practice and allocating $1.9 \mathrm{kWh} \mathrm{p}^{-1} \mathrm{~d}^{-1}$ of wheat for human food, the oilseed rape and remaining wheat could be used to produce $4.9 \mathrm{kWh} \mathrm{p}^{-1} \mathrm{~d}^{-1}$ of 
transport fuel. This represents $14 \%$ of current transport fuel consumption and exceeds the $10 \%$ target of $3.4 \mathrm{kWh} \mathrm{p}^{-1} \mathrm{~d}^{-1}$. Bioethanol production from wheat produces distiller's grains, and biodiesel from oilseed rape results in rapemeal which can both be used as an animal feed. It is assumed that all of the straw from wheat, barley, oilseed rape, and other crops was used exclusively for heating $\left(5.9 \mathrm{kWh} \mathrm{p}^{-1} \mathrm{~d}^{-1}\right)$, plus $0.6 \mathrm{kWh}$ $\mathrm{p}^{-1} \mathrm{~d}^{-1}$ from branches used as woodfuel (Figure 4a).

\subsection{Scenario 3 Monoculture wheat for maximum biofuel}

Within the Vale, wheat is one of the highest yielding crops. Scenario 3 assumed a change in current land use to planting wheat on all arable and grassland. The levels of renewable energy from wind, solar photovoltaics, municipal waste, solar water heating, ground source, and water source heating are the same as in Figure 3b. It was anticipated that transport fuel production (bio-ethanol) could reach $11.3 \mathrm{kWh} \mathrm{p}^{-1} \mathrm{~d}^{-1}$ (33\% of current demand). Assuming that all of the harvestable wheat straw was used for heating, the heat supply could reach $16.3 \mathrm{kWh} \mathrm{p}^{-1} \mathrm{~d}^{-1}$ (53\% of total demand) (Figure $4 b)$.

Insert Fig 4 here.

\section{Discussion}

\subsection{A framework to promote discussion}

As outlined in Section 1, many people find it difficult to visualise the changes in low carbon energy demand and supply that are required at local or regional levels. The energy unit used in this paper is energy demand and supply per person. In promoting discussions with local stakeholders, this approach has proved useful by creating a tangible "human-sized" measure which provides scope for an equity-based discussion. It also allows individuals within an area to recognise if, given their level of energy, food and wood consumption and the renewable energy potential of their area, they are doing or accepting 'their bit' with respect to the uptake of renewable energy. Within this analysis we have used the units of $\mathrm{kWh} \mathrm{p}^{-1} \mathrm{~d}^{-1}$. Although $\mathrm{kWh}$ is not a standard SI unit, it is the unit by which people in the UK pay for electricity and gas. It may prove useful, 
in terms of improving energy literacy and for ease of comparison, if in the future petrol and diesel prices could also be expressed in terms of $\mathrm{kWh}$. Similarly it would be useful if new vehicles were able to indicate their fuel use in terms of $\mathrm{kWh}$ in addition to miles per gallon or kilometres per litre.

\subsection{Reducing the demand for energy}

A useful feature of the framework used in this paper, is that the demand for energy, food, feed and wood is described in absolute terms against the potential supply. Current targets such as achieving a certain proportion of energy supply can draw one's focus away from the possibility of reducing demand as a method of achieving a balance between demand and supply. As illustrated in Table 4, in 2009 per capita energy use in the UK was equivalent to about $80 \mathrm{kWh} \mathrm{p}^{-1} \mathrm{~d}^{-1}$. The UK government has predicted [2] that UK energy use should be 144100 kilotonnes of oil equivalent in 2020. Because the UK population is predicted to increase ( $+8 \%$ ) from 61.4 million in 2008 to about 66.9 million in 2021 [46], the prediction for 2020 is equivalent to a per capita energy use of $68 \mathrm{kWh} \mathrm{d}^{-1}$. This is the same value that McKay [9] proposed would be possible for 2050. Reaching this value will require a $20 \%$ reduction in energy use per person over the next nine years. This can partly be achieved by reducing the demand for heating (which accounts for about a third of UK energy use) for example through roof, window and wall insulation. Other options include improvements in lighting efficiency, improved building energy management systems, and new regulations for new buildings [47]. However it is important to realise that the above value relates only to energy use within the UK. It does not include the embedded energy of items produced in other countries which are then imported into the UK [48]. Whilst moving energy intensive processes outside of the UK is one method of reducing UK energy consumption, it does not reduce energy consumption at a global level. With this qualification, the framework presented in this paper provides a mechanism by which options which reduce energy demand can be compared directly with options to increase supply.

\subsection{Reducing the demand for food and feed}

The framework also provides a per-capita estimate of the demand for food and animal feed. Two key areas for reducing these are reducing waste and reducing the consumption of animal-based products. The values used to derive the requirement for 
human food (Table 5) assumed a 10\% level of waste [15]. However WRAP [49] suggest that the proportion of the total weight of food wasted at a household level is $22 \%$ of which $63 \%$ (14\% of the total weight) is avoidable. Changes in behaviour and new technologies that can reduce food waste are obviously important. The results presented in Table 5 suggest that delivering our food energy requirements in terms of animal products typically requires about $7.8 \mathrm{kWh}$ of plant product energy for every 1 $\mathrm{kWh}$ of animal product energy. Hence initiatives to i) improve the efficiency of animal production, and ii) reduce the demand for meat and milk-based products could substantially reduce the demand for animal feed.

\subsection{Level of wood self-sufficiency}

The proportion of the land area covered by wood in the Marston Vale (8\%) is about $68 \%$ of the UK average (11.7\%). Even so, assuming typical rates of annual wood production per hectare, the analysis showed that the Marston Vale was only able to supply $22 \%$ of its wood requirements. The framework therefore highlights the low level of self-sufficiency and the dominance of imported wood within the UK. In 2005, the UK imported about $68 \%$ of the wood (sawnwood, wood-based panels, paper and paperboard) that it consumed [19]. Because about $60 \%$ of the consumption was related to paper manufacture, reduced and more efficient use of paper could produce significant benefits.

\subsection{Relative magnitude of the demand for energy and food}

Describing energy and food on a common scale highlights that the demand for delivered energy (currently $80 \mathrm{kWh} \mathrm{d}^{-1} \mathrm{p}^{-1}$ ) is an order of magnitude greater than our demand for food and feed $\left(7.5 \mathrm{kWh} \mathrm{d}^{-1} \mathrm{p}^{-1}\right)$. It is also six-times greater than the current supply of food and feed $\left(13.6 \mathrm{kWh} \mathrm{d}^{-1} \mathrm{p}^{-1}\right)$ from the Marston Vale, which has a similar population density midway between that for the UK and England (Table 13). This difference highlights the major limitations in using biomass production within the UK to address issues of energy security particularly when high food prices are a concern for many. Even if the total arable and grassland area was planted to a highly productive crop like wheat, the Marston Vale could only supply $11 \mathrm{kWh} \mathrm{d}^{-1} \mathrm{p}^{-1}(33 \%)$ of the current demand for transport fuel, and $16 \mathrm{kWh} \mathrm{d}^{-1} \mathrm{p}^{-1}(53 \%)$ of the demand for heat energy. Moreover this is only achievable by annually using all of the harvested straw for heating, and in 
the medium- to long-term this will lead to reduced soil organic matter levels and reduced yields.

Insert Table 13 here.

\subsection{Forms of energy}

The analysis has considered energy in the form of electricity, transport fuel and heat. Each form has different properties in terms of its storage, transport and thermodynamic 'quality' [50]. The chemical energy embedded in fuels is considered to have a high thermodynamic quality and it can be stored until required. Electricity also has a high thermodynamic quality but it is currently difficult to store; conversely heat energy is considered to have a low thermodynamic quality and it is difficult to store and transport. However where it can be used, the efficiency of obtaining heat from a fuel (80\%) is substantially higher than that for electricity (30\%). In practice it is possible to use a combined heat and power (CHP) plant to use the heat at the same time as generating electricity. However the success of such systems typically requires enterprises close to the power-plant which can benefit from a year-round supply of heat.

\subsection{Difficulty in producing transport fuel}

Scenario 3 shows that the Marston Vale (with a population density of 3.1 people $\mathrm{ha}^{-1}$ ) could only supply $33 \%$ of the current demand for transport fuel $\left(34 \mathrm{kWh} \mathrm{p}^{-1} \mathrm{~d}^{-1}\right)$, even if all of the arable and grassland area was planted to wheat. By contrast, assuming a high level of wind turbines or the short- to medium-term production of electricity from landfill gas, there appears to be potential to increase renewable electricity production. This analysis would support the observation made by others [9] that transport will become increasingly electricity-based within a low carbon economy.

\subsection{Electricity generation}

The calculations show that within the Marston Vale, wind seems to offer the greatest potential for electricity generation. The construction of 98 wind turbines, which would cover about $7 \%$ of the area, was estimated to produce the equivalent of $21 \mathrm{kWh} \mathrm{p}^{-1} \mathrm{~d}^{-1}$. This is similar to the value of $20 \mathrm{kWh} \mathrm{p}^{-1} \mathrm{~d}^{-1}$, calculated by MacKay [9] for onshore wind turbines covering $10 \%$ of the UK. In this analysis we have only focussed on terrestrial sources, but many studies have also placed emphasis on off-shore wind. For 
example the Centre for Alternative Technology [51] in their Zero Carbon Britain 2020 scenario assumed that $52 \%$ of the indigenous UK energy production would come from off-shore wind. However even with a countrywide network, the temporal variability in wind speeds means that alternative methods of producing electricity and/or managing energy demand are still required.

The assumed annual electrical energy yield from solar photovoltaics of $117 \mathrm{kWh} \mathrm{m}^{-2}$ appears to be at the top end of outputs reported from currently installed systems. For example Tovey and Turner [52] report an output of $74 \mathrm{kWh} \mathrm{m}^{-2}$ for a roof-mounted mono-crystalline system in Eastern England. Our analysis shows the limited potential of solar photovoltaics $\left(1.6 \mathrm{kWh} \mathrm{p}^{-1} \mathrm{~d}^{-1}\right)$ if they are limited to only one-eighth of the area of domestic housing ( $5 \mathrm{~m}^{2}$ of panel per person). MacKay [9] proposed a potential output from photovoltaics of $5 \mathrm{kWh} \mathrm{p}^{-1} \mathrm{~d}^{-1}$, but this was based on the equivalent of 10 $\mathrm{m}^{2}$ of photovoltaic panels per person. Although not considered in this paper, there is also the potential possibility of the creation of solar farms.

\subsection{Heating}

The value estimated for solar water heating $\left(1.4 \mathrm{kWh} \mathrm{d}^{-1}\right)$ from a $1 \mathrm{~m}^{2}$ panel is similar to the value of $3.8 \mathrm{kWh} \mathrm{d}^{-1}$ for a $3 \mathrm{~m}^{2}$ panel reported by MacKay [9]. However whereas we have assumed only $1 \mathrm{~m}^{2}$ of solar heating panel per person, MacKay assumed that each person could install $10 \mathrm{~m}^{2}$ of panels $\left(13 \mathrm{kWh} \mathrm{p}^{-1} \mathrm{~d}^{-1}\right)$. The lower estimate presented here seems to be closer to the current practice of installing systems that match water heating requirements during the summer. Because of the difficulty in installing ground-source heating in existing buildings, ground-source heating was only assumed in new properties. In an area such as the Marston Vale where substantial levels of new housing are planned, such heating could be significant $\left(6.5 \mathrm{kWh} \mathrm{p}^{-1} \mathrm{~d}^{-1}\right)$ (Table 8). However this output also requires an electrical input for pumping equivalent to $1.8 \mathrm{kWh}$ $\mathrm{p}^{-1} \mathrm{~d}^{-1}$. In order to maximise the energy gains from the system, it is desirable that the electricity used to drive the pump is derived from a non-biomass source.

\subsection{Landfill energy}

In the three scenarios, energy derived from landfill gas was ignored. Landfill in the Marston Vale is currently assumed to be contributing electricity equivalent to $14 \mathrm{kWh}$ p 
${ }^{1} \mathrm{~d}^{-1}$; at present there is minimal use of the heat generated. Assuming that it was possible to use to the landfill gas for combined heat and power generation, then the landfill gas could generate about $23 \mathrm{kWh} \mathrm{p}^{-1} \mathrm{~d}^{-1}$. Over the short-term this could be a very significant energy source equivalent to nearly all of the predicted local demand for electricity and most of the heat. However over the long-term the energy produced will decrease as landfill gas yields decline; although the rate of the reduction is difficult to determine. Although landfill gas is an important source of renewable energy in the UK, it particular prominence in the study area is untypical for the UK as a whole, being a result of local clay geology, the availability of large pits associated with brick manufacturing, and proximity to large population centres such as London.

\subsection{Greenhouse gas savings}

The presumption in this paper is that the renewable energies described result in lower net greenhouse gas emissions than the extraction and use of fossil fuels. Even amongst fossil fuels, the amount of carbon dioxide emitted per energy output depends on both the fuel source and the type of energy delivered [50]. For example the supply of $1 \mathrm{kWh}$ of electricity results in $882 \mathrm{~g} \mathrm{CO}_{2}$ if produced from coal and $376 \mathrm{~g} \mathrm{CO}_{2}$ if produced from gas [53]. These are similar to values of 945 and $424 \mathrm{~g} \mathrm{CO}_{2} \mathrm{kWh}^{-1}$ for electricity production from coal and gas respectively as reported by Cannell [54]. Assuming that the carbon contained in the biomass would not have been sequestered in the absence of harvesting that crop, then the predicted emission from an electrical power plant using biomass has been estimated to be $44 \mathrm{~g} \mathrm{CO}_{2} \mathrm{kWh}^{-1}$ [54]. This may be the case of sustainable biomass removal from a mature forest. However in other situations the harvesting of biomass could simply be reducing the natural sequestration of carbon.

The extraction and use of petrol and diesel have been estimated to result in the emission of 293-315 $\mathrm{g} \mathrm{CO}_{2}$ equivalent $\mathrm{kWh}^{-1}$ [55]. By contrast net greenhouse emissions for the production of bioethanol from wheat range from 42 to $228 \mathrm{~g} \mathrm{CO}_{2}$ equivalent $\mathrm{kWh}^{-1}$, and that for biodiesel from oilseed rape ranges from -20 to $166 \mathrm{~g} \mathrm{CO}_{2}$ equivalent $\mathrm{kWh}^{-1}$ [55]. These values represent net greenhouse gas savings of between 22 and $106 \%$ depending on the use of the co-products, soil type, and previous land use. Converting arable land to perennial crops such as woodland, short rotation coppice, miscanthus or grass, is usually beneficial in reducing the oxidation of soil carbon [56]. By contrast, 
converting grasslands and forests into cultivated arable land will reduce the net greenhouse gas emission benefits. The reduction of soil carbon caused by removing straw, rather than incorporating into the soil, will also reduce the net benefit if straw is used as an energy source. The scenarios described in this paper need to analysed further to predict their effect on net greenhouse gas emissions.

\subsection{Ecosystem services}

Effects of renewable energy supply on ecosystem services go beyond the three provisioning services of food, feed and wood considered here. Increased biomass fuel production from perennial crops can also lead to increased competition for water supply, but positive effects on water quality. There are also effects on other ecosystem services such as soil carbon, habitat creation, and cultural services such as recreational opportunities. Such services are also important for human well-being and the impact of such services will be explored in future papers.

\section{Conclusions}

Energy policy was traditionally set at the national level, whilst energy consumption was studied for individual households. The framework used in this paper enables the development of energy scenarios at any intermediate geographical scale between the national level and the household level, linking local production potential with the local level of consumption, and exploring the synergies and trade-offs between local renewable energy production on the one hand and the production of other land-based commodities on the other. By expressing the demand and supply of energy (electricity, transport and heat), food, animal feed and wood in a common per capita unit, this framework can be used to examine how a range of national policies - on energy, housing, agriculture, land use could be implemented in a balanced and integrated way at the local level. The development of scenarios to explore what can be done locally, can help to inform local planning decisions and facilitate public engagement in the (otherwise rather abstract) energy debate on a more concrete and contextualised basis. To the extent that the population density in the Marston Vale is similar to that in the UK, the study also serves as a microcosm of the UK energy landscape. Finally, the framework lends itself for further extensions, e.g. to compare the options in terms of net greenhouse gas emissions, finance, and public perceptions. 


\section{Acknowledgements}

The research described was funded by a Natural Environment Research Council (NERC) grant (reference NE/H010432/1). The group wishes to express their thanks to those who have commented and made positive suggestions about the work and all the stakeholders, colleagues and students who have assisted in the process.

\section{References}

[1] Department for Trade and Industry (DTI) (2000). New \& Renewable Energy: Prospects for the 21st Century, The Renewables Obligation Preliminary Consultation; 2010, accessed 28 June 2010 at http://www.berr.gov.uk/files/file21097.pdf.

[2] DECC (Department of Energy and Climate Change). National Renewable Energy Action Plan for the United Kingdom. Article 4 of the Renewable Energy Directive. 2010, accessed 4 May 2011 at http://www.decc.gov.uk/assets/decc/what\%20we\%20do/uk\%20energy\%20supply/ energy\%20mix/renewable\%20energy/ored/25-nat-ren-energy-action-plan.pdf

[3] DECC (Department of Energy and Climate Change). Energy consumption in the UK; overall data tables 2009 update; 2009, accessed 5 July 2010 at http://www.decc.gov.uk/en/content/cms/statistics/publications/ecuk/ecuk.aspx

[4] Millennium Ecosystem Assessment. Ecosystems and Human Well-being: Synthesis. Washington DC: Island Press. 2005

[5] De Groot, R. Function-analysis and valuation as a tool to assess land use conflicts in planning for sustainable, multi-functional landscapes. Landscape and Urban Planning (2006) 75, 175-186.

[6] De Groot, R.S., Wilson, M.A. \& Boumans, R.M.J. A typology for the classification, description and valuation of ecosystem functions, goods and services, Ecological Economics (2002) 41, 393 - 408.

[7] Office for National Statistics. Social Trends 40; 2010 accessed on 4 May 2011 at http://www.statistics.gov.uk/downloads/theme_social/SocialTrends40/ST40_2010_FINAL.pdf

[8] Angus, A., Burgess, P.J. Morris, J. \& Lingard, J.. Agriculture and land use: demand for, and supply of, agricultural commodities, characteristics of the farming and food industries, and their implications for land use in the UK. Land Use Policy (2009) 26S: S230-S242.

[9] MacKay, D.J.C. Sustainable Energy - Without the Hot Air. Cambridge: UIT Cambridge Ltd. 2009.

[10] Boyle, G. Renewable Energy - Power for a Sustainable Future, $2^{\text {nd }}$ ed., Oxford: Oxford University Press. 2004

[11] DECC (Department of Energy and Climate Change). Sub-National Energy Consumption Statistics; 2010; accessed on 5 May 2011 at http://www.decc.gov.uk/en/content/cms/statistics/regional/regional.aspx 
[12] CIBSE (Chartered Institution of Building Services Engineers). Energy Efficiency in Buildings. CIBSE Guide. London: CIBSE. 1998.

[13] Williams, A.G., Audsley, E. \& Sanders, D.L.. Determining the Environmental Burdens and Resource Use in the Production of Agricultural and Horticultural Commodities. Main report. Defra Research Project ISO205. Bedfordshire: Cranfield University and Defra. 2006.

[14] DECC (Department of Energy and Climate Change) (DECC). Digest of United Kingdom Energy Statistics 2009; 2009, accessed 5 May 2011 at http://www.decc.gov.uk/assets/decc/Statistics/publications/dukes/1_20100208131 106_e@@@dukes09.pdf

[15] DEFRA (Department for Environment, Food and Rural Affairs). Family Food - A report on the 2008 Family Food Module of the Living Costs and Food Survey, 2010. Accessed 5 May 2011 at

http://www.defra.gov.uk/statistics/files/defra-stats-food-family-annual-2008.pdf

[16] FAO. Food Energy - Methods of Analysis and Conversion Factors. Report of a Technical Workshop. Rome, 3-6 December 2002. 2003. Accessed 5 May 2011 at http://www.fao.org/docrep/006/y5022e/y5022e00.htm\#Contents

[17] Pimental, D. \& Pimental, M. Sustainability of meat-based and plant-based diets and the environment. The American Journal of Clinical Nutrition (2003) 78(suppl), 660S-663S.

[18] Alexandratos, N., Bruinsma, J., Bödeker, G., Schmidhuber, J., Broca, S., Shetty, P. \& Ottaviani, M.. Prospects for food, nutrition, agriculture \& major commodity groups. World Agriculture towards 2030/2050. Interim Report. Global Perspectives Studies Unit. FAO: Rome. 2006

[19] Forestry Commission (2006). Forestry Statistics 2006. 2006, accessed on 20 July 2010 at http://www.forestry.gov.uk/website/ForestStats2006.nsf/byunique/imports.html,

[20] Nabuurs, G.J., Ravindranath, N.H., Paustian, K., Freibauer, A., Hohenstein, W \& Makundi, W.. Chapter 3 LUCF Sector Good Practice Guidance. In: IPCC Good Practice Guidance for Land Use Change and Forestry (Eds: J. Penman, M. Gytarsky, T. Hiraishi, T. Krug, D. Kruger, R. Pipatti, L. Buendia, K. Miwa, T. Ngara, K. Tanabe \& F. Wagner). Kanagawa, Japan: IPCC National Greenhouse Gas Inventories Programme. 2003. Accessed on 4 May 2011 at http://www.ipccnggip.iges.or.jp/public/gpglulucf/gpglulucf_files/Chp3/Anx_3A_2_0_Reporting Tables_Cover.pdf

[21] Kaltschmitt, M., Thrän, D., \& Smith, K.R.. Renewable Energy from Biomass. Encyclopedia of Physical Sciences and Technology. Third Edition Volume 14: 203-228. Burlington, MA: Academic Press/Elsevier. 2002

[22] DCLG (Department for Communities and Local Government) (2007). Generalised Land Use Database Statistics for England 2005. 2007. Accessed on 4 May 2011 at 
http://www.communities.gov.uk/publications/planningandbuilding/generalisedlan duse

[23] Jardine C.N. \& Lane K. Photovoltaics in the UK: An Introductory guide for new consumers. Environmental Change Institute. University of Oxford. Oxford - ECI Research Report No. 27. 2003

[24] Armitage, E., Badmos, B., Barber, C., Boye, A., Brown, P., Corney Riera, A., De Brogniez, D., Denicolai, M., Dickins, E., Dudziuk, Z., Dufosse, K., Eckhard, K., Filipkowska, E., Garcia Garcia, V., Gavu, J., George, C., Hailes-Parry, D., Harrison, M., Jarratt, A., Kral, F., Mannion, A., Meyer, V., Nott, T., Okube Mezengie, Z., Osinski, P., Sarlej. R., Vylupek, O., Wallwork, A., Williams, M., Wright, K. and Zemanova, M. Energyscapes and Ecosystem Services of the Marston Vale, Unpublished MSc Land Management and Geographical Information Management Group Project. Cranfield: Cranfield University. 2010

[25] National Energy Foundation. Wind Turbine Feasibility at the Millennium Country Park, Marston Moretaine. National Energy Foundation: Milton Keynes, UK. 24 pp. 2007.

[26] ENTEC. Marston Vale Trust Marston Mill Wind Turbine Planning Statement. 100 pp. 2010. Accessed on 5 July 2010 at http://www.centralbedfordshire.gov.uk/portal/showimage.asp?j=CB/10/01359\&in $\underline{\mathrm{dex}}=333984$

[27] Energy Saving Trust. Location, Location, Location. Domestic small-scale Wind Field Trial Report. 2009. Accessed on 4 May 2011 at http://www.energysavingtrust.org.uk/Media/node_1422/Location_location_locati on-_wind_trials_report

[28] Renewable UK. Reference: UK wind speed database. 2010. Accessed 23 July 2010 at http://www.bwea.com/noabl/index.html.

[29] Energy Savings Trust. Measurement of Domestic Hot Water Consumption in Dwellings. 2008. Accessed on 4 May 2011 at: http://www.decc.gov.uk/assets/decc/what\%20we\%20do/supporting\%20consumer s/sustainable\%20energy\%20research\%20analysis/1_20090710110453_e_@@9 measurementofdomestichotwaterconsumptionindwellingsmarch2008.pdf

[30] NHBC Foundation. A Review of Micro-generation and Renewable Energy Technologies. Amersham: NHBC Foundation. 57 pp. 2008

[31] Utley, J.I. \& Shorrock, L.D. Domestic Energy Fact File 2008. 2008. Accessed on 4 May 2011 at http://www.bre.co.uk/filelibrary/pdf/rpts/Fact_File_2008.pdf

[32] DCLG (Department for Communities and Local Government). English Housing Survey: Housing Stock Report 2008. 2010. Accessed on 4 May 2011 at http://www.communities.gov.uk/documents/statistics/pdf/1750754.pdf

[33] Covanta Energy Ltd. Combined Heat and Power Development Strategy. 2010. Accessed on 4 May 2011 at http://infrastructure.independent.gov.uk/wpcontent/ipc/uploads/projects/EN010011/2.\%20Post- 
Submission/Application\%20Documents/Other\%20Documents/Combined\%20Hea t\%20and\%20Power\%20Report.PDF

[34] Renewable Energy Foundation. Renewable Obligation Generators. 2011. Accessed 30 March 2011 at http://www.ref.org.uk/roc-generators/

[35] Van der Werf, W., Keesman, K., Burgess, P.J., Graves, A.R., Pilbeam, D, Incoll, L.D, Metselaar, K., Mayus, M., Stappers, R., van Keulen, H., Palma, J \& Dupraz, C. Yield-SAFE: a parameter-sparse process-based dynamic model for predicting resource capture, growth and production in agroforestry systems. Ecological Engineering (2007) 29, 419-433.

[36] Richter, G.M., Riche, A.B., Dailey, A.G., Gezan, S.A. \& Powlson, D.S. Is UK biofuel supply from Miscanthus water-limited? Soil Use and Management (2008) $24,235-245$.

[37] Aylott, M.J. Casella, E., Tubby, I, Street, N.R., Smith, P. \& Taylor, G. Yield and spatial supply of bioenergy poplar and willow short-rotation coppice in the UK. New Phytologist (2008) 178: 358-370.

[38] Mortimer, N.D., Elsayed, M.A., \& Horne, R.E.. Energy and greenhouse gas emissions from bioethanol production from wheat grain and sugar beet. Sheffield Hallam University. 2004.

[39] Mortimer, N.D., Cormack, P., Elsayed, M.A. \& Horbe, R.E.. Evaluation of the comparative energy, global warming and socio-economic costs of biodiesel. Sheffield-Hallam. 2003.

[40] Norman, K., Burgess, P.J., Yeomans, A. \& Hemery, G. Woodfuel and woodland management: a case study. Quarterly Journal of Forestry (2011) 105(2): 135-140.

[41] Noblet, J., Fortune, H., Dupire, C. \& Dubois, S. Digestible, metabolisable \& net energy values of 13 feedstuffs for growing pigs: effect of energy system. Animal Feed Science \& Technology (1993) 42, 131-149.

[42] Fehrenbach, H., Giegrich, J., Gärtner, S., Reinhardt, G. \& Rettenmaier, N. Greenhouse Gas Balances for the German Biofuels Quota Legislation. Methodological Guidance and Default Values. Prepared for the Federal Environment Agency Germany. 2007. Accessed on 4 May 2011 at http://www.ifeu.de/nachhaltigkeit/pdf/Methodology\%20for\%20biofuels $\% 20$ \%20default\%20values\%20IFEU\%20Germany.pdf

[43] McDonald, P., Edwards, R.A \& Greenhalgh, J.F.D. Animal Nutrition. Third Edition. London: Longman. 1981

[44] Bonnadeaux, J. Potential uses for distiller grains. Department of Agriculture and Food, Government of Western Australia. 2008.

[45] FAO. Unified Bioenergy Technology. FAO Forestry Department Wood Energy Programme. 50 pp. 2004. Accessed on 4 May 2011 at: http://www.fao.org/docrep/007/j4504e/j4504e01.htm\#TopOfPage

[46] Office for National Statistics. National Population Projections 2008-based. 2008. Accessed on 4 May 2011 at http://www.statistics.gov.uk/downloads/theme_population/pp2no27.pdf 
[47] Toke, D \& Taylor, S. Demand reduction in the UK - with a focus on the nondomestic sector. Energy Policy (2007) 35: 2131-2140.

[48] Wiedmann, T. A first empirical comparison of energy footprints embodied in trade - MRIO versus PLUM. Ecological Economics (2009) 68: 1975-1990.

[49] WRAP (Waste and Resource Action Plan). The Food We Waste. Project RBC 405-0010, July 2008. Banbury: WRAP-Waste and Resource Action Plan. 2008.

[50] Allen, S.R. \& Hammond, G.P. Thermodynamic and carbon analyses of microgenerators for UK households. Energy (2010) 35: 2223-2234.

[51] Centre for Alternative Technology (CAT). Zero Carbon Britain 2030: A new strategy, UK. Machynlleth, Powys: CAT Publications. 2010.

[52] Tovey, K. \& Turner, C. Performance of two photovoltaic arrays in the UK. Proceedings of the Institution of Civil Engineers (2008) 161, Issue EN1, 11-21.

[53] DECC (Department of Energy and Climate Change). Statistical Release - UK Climate Change Sustainable Development Indicator: 2009 greenhouse gas emissions, provisional figures and 2008 greenhouse gas emissions, final figures by fuel type and end-user, 2010. Accessed on 4 May 2011 at http://www.decc.gov.uk/assets/decc/statistics/climate_change/1_20100325084241 _e_@@_ghgnationalstatsrelease.pdf.

[54] Cannell, M.G.R. Carbon sequestration and biomass energy offset: theoretical, potential and achievable capacities globally, in Europe and the UK. Biomass and Bioenergy (2003) 24, 97-116.

[55] Royal Society. Sustainable Biofuels: Prospects and Challenges. London: Royal Society. 2008.

[56] Ostle, N. J., Levy, P. E., Evans, C. D. \& Smith, P. UK land use and soil carbon sequestration. Land Use Policy (2009) 26S, S274 - S283. 


\section{Figures}

Fig. 1. Modelled land use within the Marston Vale in 2009 a) without and b) with consented development.

Fig. 2. Total (dotted area) and the 2020 renewable target (in red) demand for electricity, transport fuels, and heat, and the demand (also in red) for food (crops for human consumption), animal feed (crops and grass), and wood.

Fig 3. Scenario 1: comparison of the anticipated renewable energy targets for 2020 (red) and the total demand (dotted outline) for energy, food, feed and wood, with the possible supply assuming no use of biomass or landfill for renewable energy and assuming a) 7 wind turbines and b) 98 wind turbines.

Fig 4. Comparison of renewable energy targets for 2020 (red) and the total demand (dotted outline) for energy, food, feed and wood with the predicted supply, assuming a) Scenario 2 where current land use is maintained but all wheat grain and oilseed is used for the production of transport fuel (once human crop food requirements are met), and b) Scenario 3 where wheat is planted on all agricultural areas. In each case, all straw and branches are used for heating, and distillers grains from the wheat and rapemeal from the oilseed is used as animal feed. 
a) Modelled land use in 2009

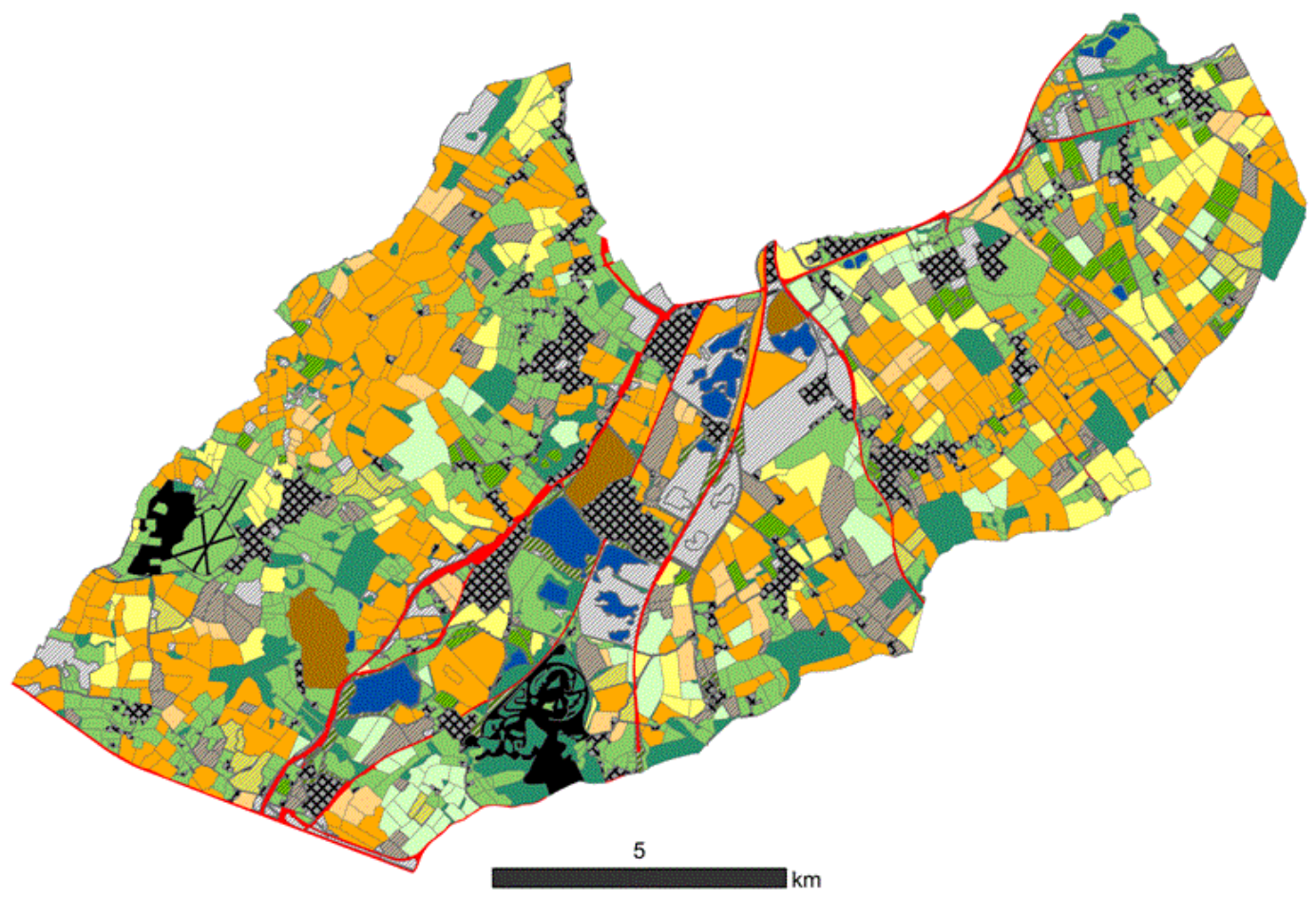

b) Land use in 2009 plus consented developments

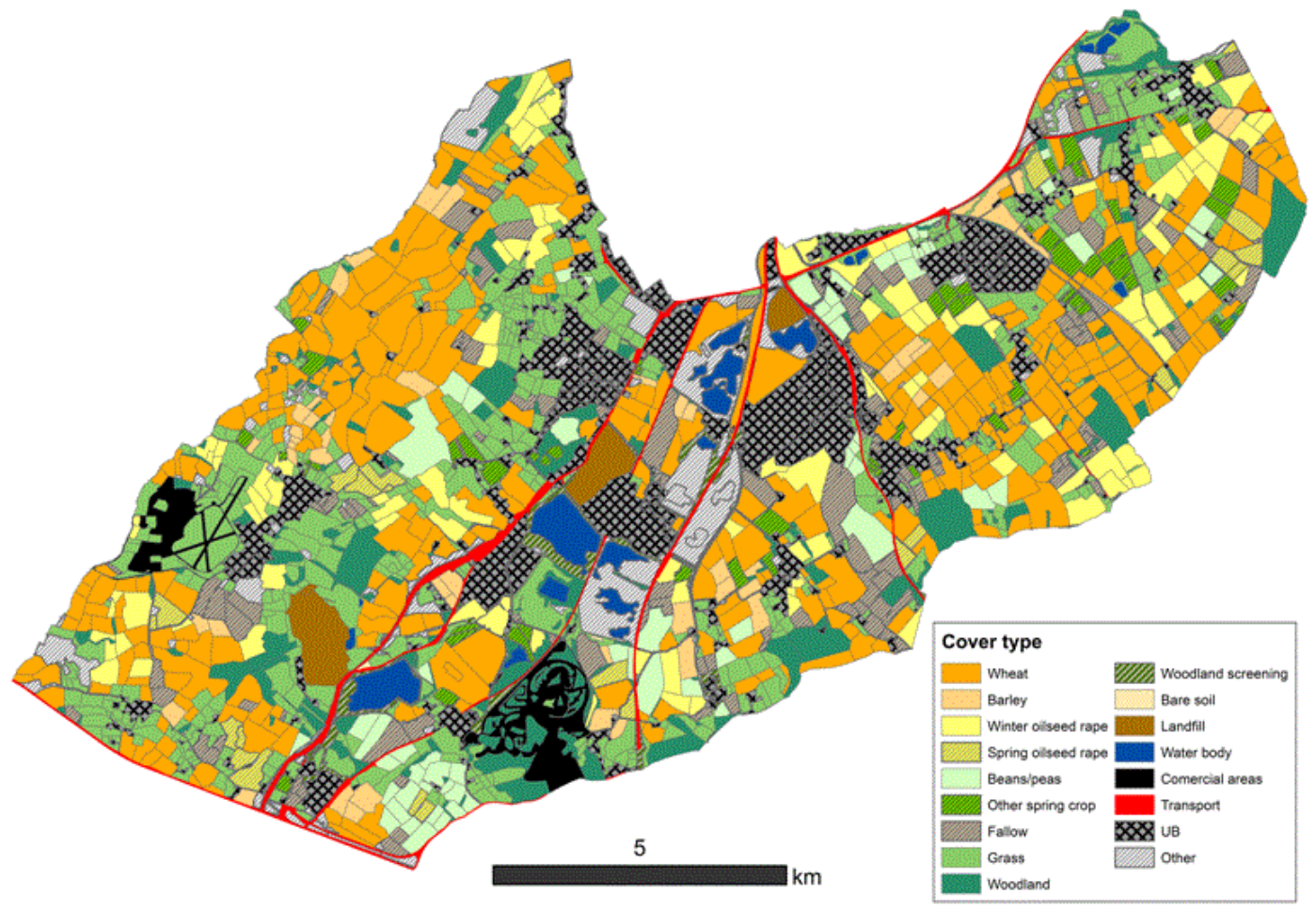

Figure 1. 


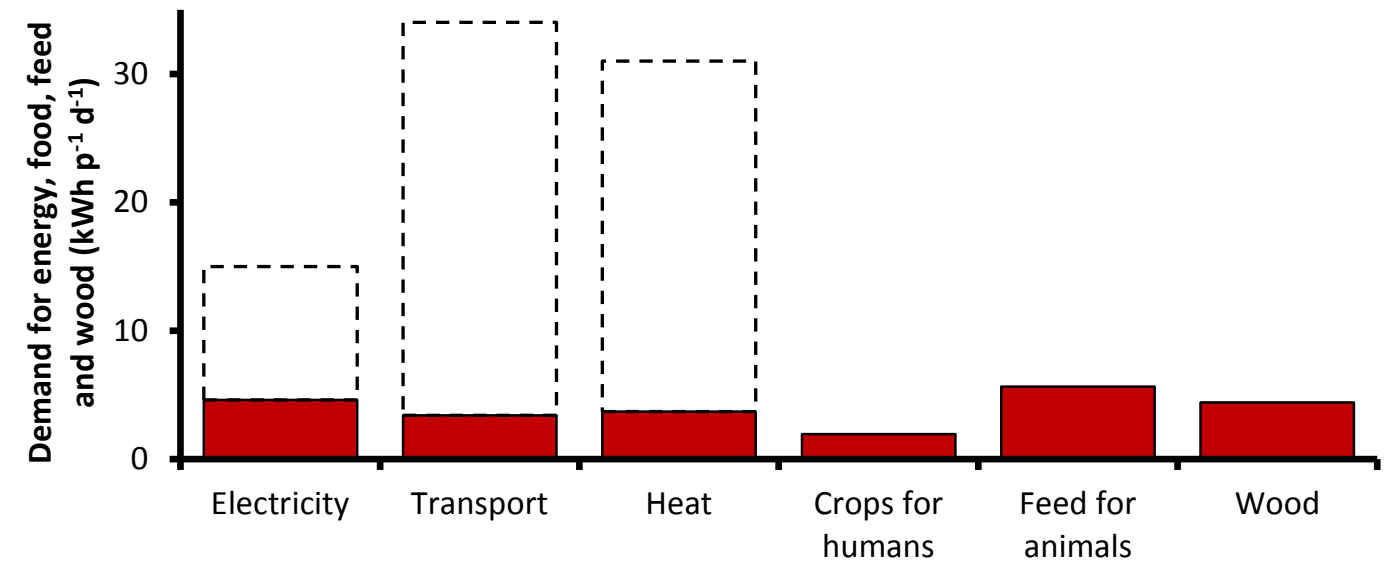

Figure 2 
a) Scenario 1: seven wind turbines

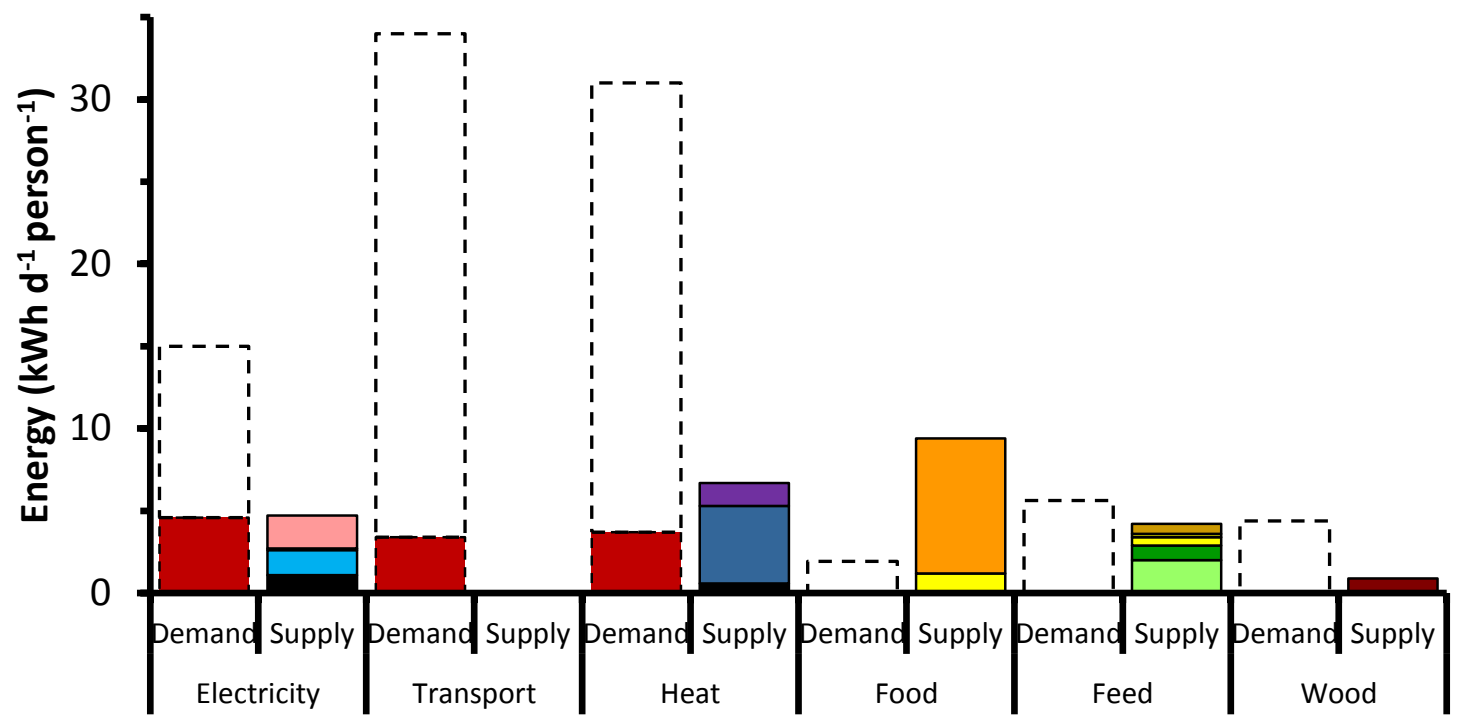

b) Scenario 1: 98 wind turbines

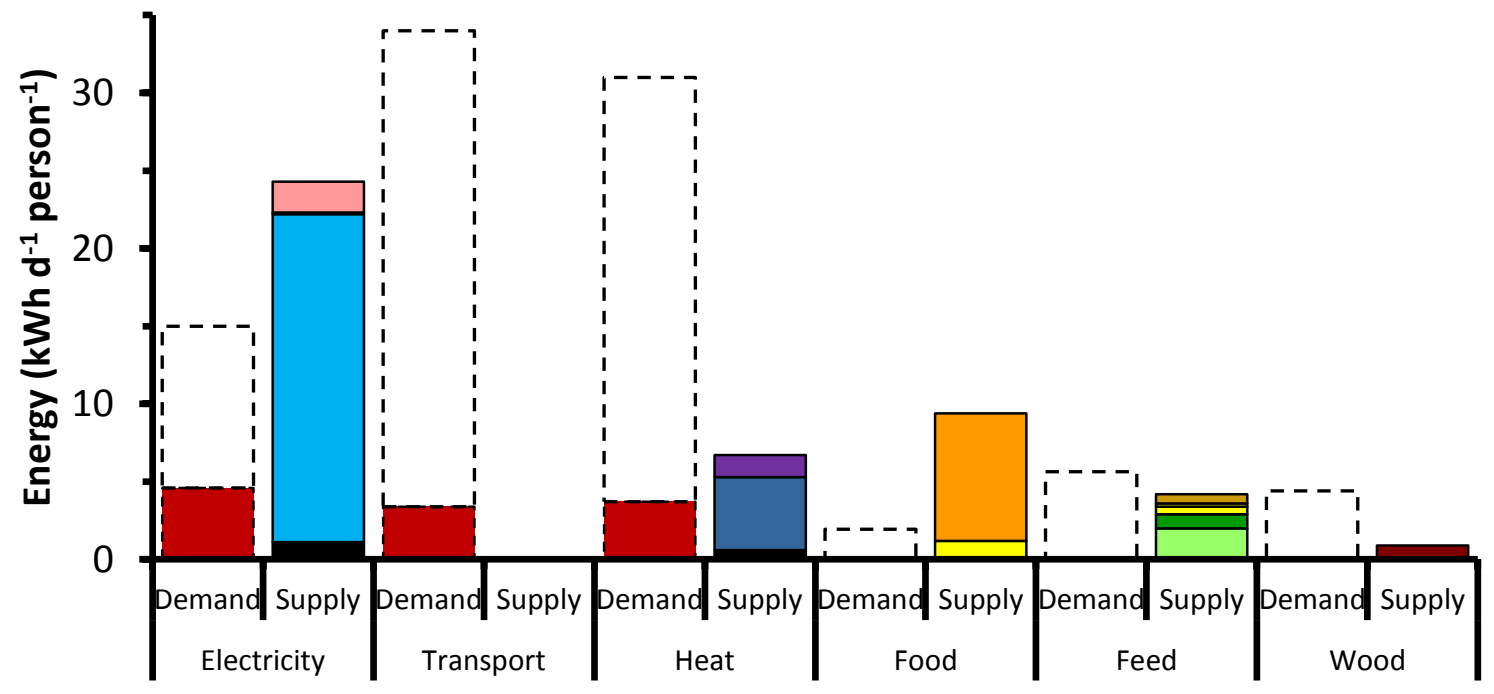

$\begin{array}{llll}\text { L-iTotal demand } & \square \text { Renewable target } & \square \text { Solar water } & \square \text { Groundsource } \\ \square \text { Photovoltaic } & \square \text { Domestic wind } & \square \text { Wind turbines } & \square \text { Municipal waste } \\ \square \text { Landfill } & \square \text { Wheat grain } & \square \text { Wheat straw } & \square \text { Barley grain } \\ \square \text { Barley straw } & \square \text { OSR oilseed } & \square \text { OSR straw } & \square \text { Other food } \\ \square \text { Other straw } & \square \text { Grass } & \square \text { Wood } & \end{array}$

Fig. 3. 
a) Scenario 2

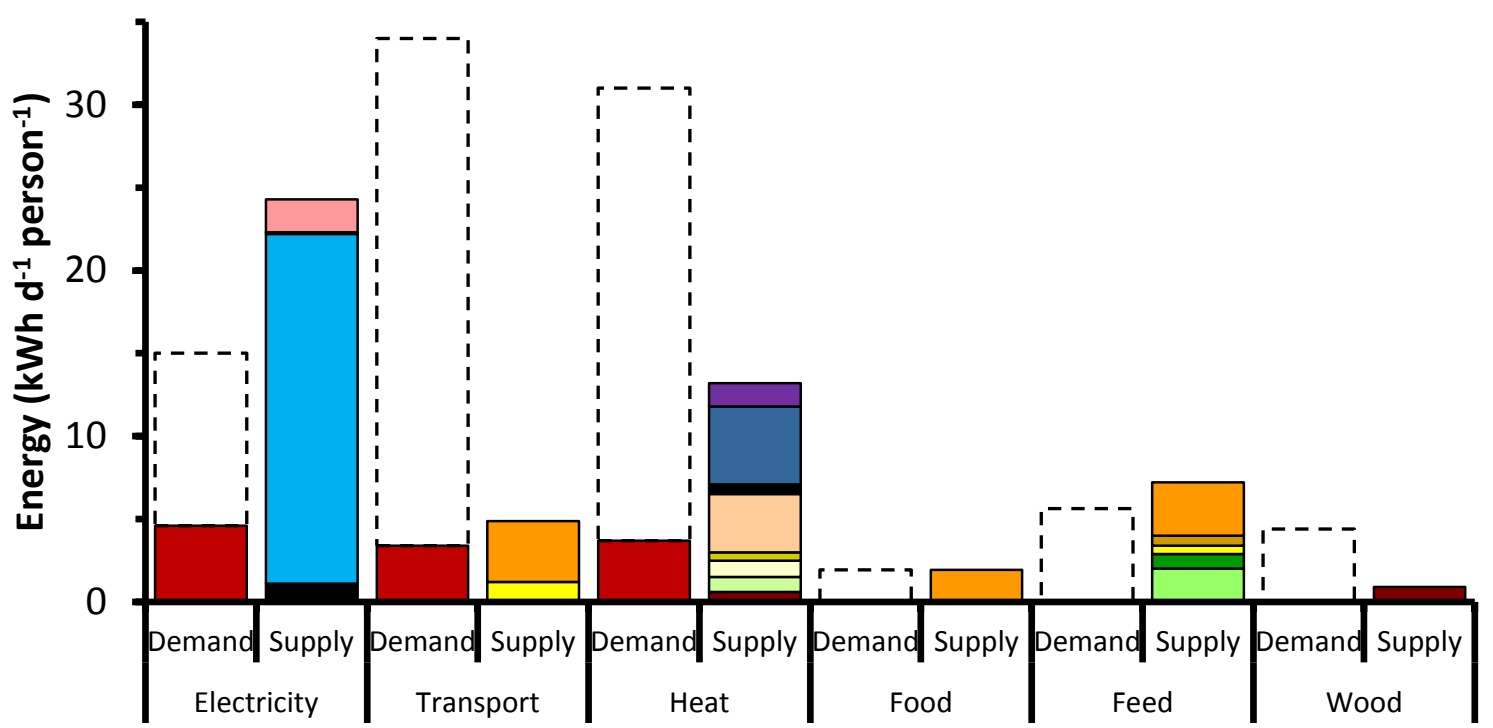

b) Scenario 3

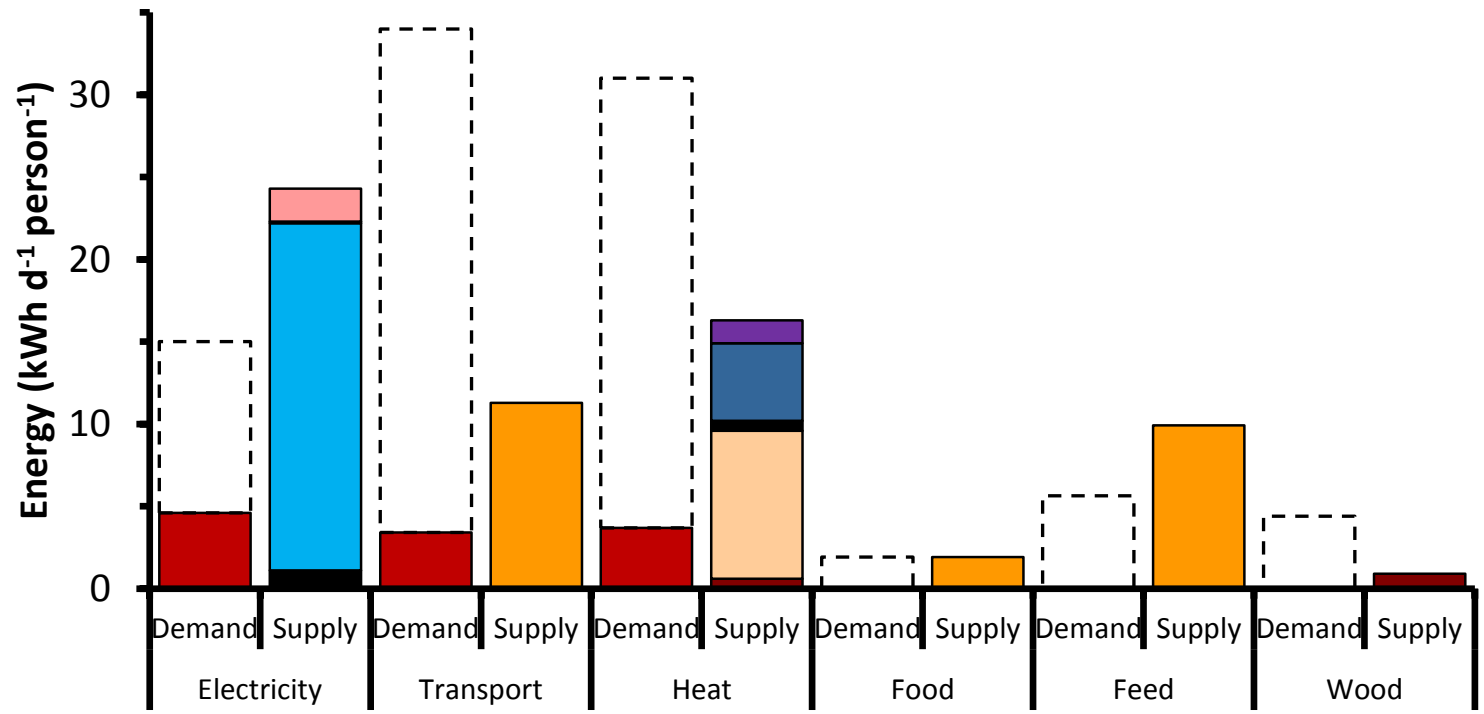

$\begin{array}{llll}\text { L-Total demand } & \square \text { Renewable target } & \square \text { Solar water } & \square \text { Groundsource } \\ \square \text { Photovoltaic } & \square \text { Domestic wind } & \square \text { Wind turbines } & \square \text { Municipal waste } \\ \square \text { Landfill } & \square \text { Wheat grain } & \square \text { Wheat straw } & \square \text { Barley grain } \\ \square \text { Barley straw } & \square \text { OSR oilseed } & \square \text { OSR straw } & \square \text { Other food } \\ \square \text { Other straw } & \square \text { Grass } & \square \text { Wood } & \end{array}$

Fig 4. 
Table 1. Ecosystem services can be categorised into five functional groups as described by De Groot et al [6] and De Groot [5]. The focus of this paper is on the production and carrier functions.

\begin{tabular}{lll}
\hline $\begin{array}{l}\text { Functional } \\
\text { group }\end{array}$ & Description & Examples services \\
\hline Production & $\begin{array}{l}\text { Production of carbohydrate } \\
\text { structures }\end{array}$ & $\begin{array}{l}\text { Food, animal feed, energy } \\
\text { resources, genetic material }\end{array}$ \\
\hline Carrier & $\begin{array}{l}\text { Providing a space and substrate for } \\
\text { human infrastructure }\end{array}$ & $\begin{array}{l}\text { Housing, transport, non-biomass } \\
\text { energy supply, waste storage }\end{array}$ \\
\hline Regulating & $\begin{array}{l}\text { Bio-geochemical cycles and } \\
\text { biospheric processes } \\
\text { Providing opportunities for } \\
\text { Cultural }\end{array}$ & $\begin{array}{l}\text { Carbon dioxide, oxygen, climate, } \\
\text { water and soil regulation } \\
\text { Recreational and cultural spaces, }\end{array}$ \\
Habitat & $\begin{array}{l}\text { Providing habitat for wild plants } \\
\text { and animals }\end{array}$ & Designated conservation areas \\
\hline
\end{tabular}


Table 2. Categories of land use used within the geographical information system

\begin{tabular}{ll}
\hline Class & Categories \\
\hline Agricultural land & Wheat, winter oilseed rape, spring oilseed rape, barley, \\
& beans/peas, other spring crop, fallow, bare soil, grass \\
Woodland & Woodland, woodland screening \\
Other & $\begin{array}{l}\text { Water, urban, transport infrastructure, commercial area, } \\
\text { landfill, other }\end{array}$ \\
\hline
\end{tabular}

Table 3. Estimated land use (ha) in Marston Vale in 2009 (without and with consented development) based on a matrix of $100 \mathrm{~m}$ x $100 \mathrm{~m}$ pixels. Values in brackets are percentages $(\%)$.

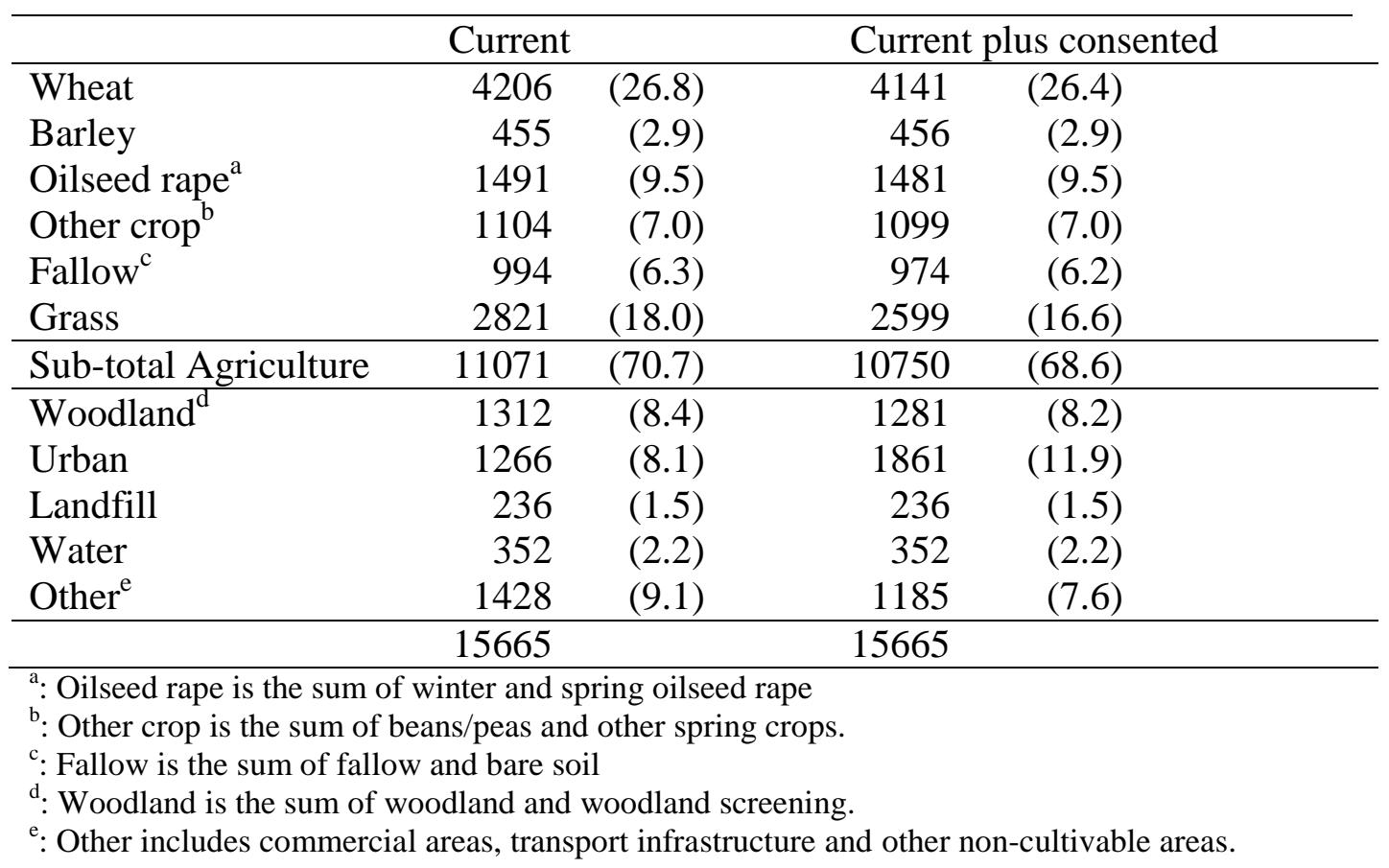


Table 4. Estimates of current energy use within Marston Vale and the UK. The UK values also include illustrative renewable energy targets for 2020.

\begin{tabular}{llrrrr}
\hline Area & Source & Electricity & Transport & Heat $^{\mathrm{c}}$ & Total \\
\hline Marston & Domestic $(\mathrm{GWh})$ & 53 & 154 & 172 & 379 \\
Vale & Commercial $(\mathrm{GWh})^{\mathrm{a}}$ & 75 & 168 & 97 & 340 \\
& Agricultural $(\mathrm{GWh})^{\mathrm{b}}$ & 12 & 13 & 12 & 35 \\
& Total $(\mathrm{GWh})$ & 140 & 335 & 281 & 754 \\
& Total $\left(\mathrm{kWh} \mathrm{p}^{-1} \mathrm{~d}^{-1}\right)$ & 15 & 36 & 30 & 81 \\
\hline UK [14] & Total $\left(\mathrm{kWh} \mathrm{p}^{-1} \mathrm{~d}^{-1}\right)^{\mathrm{c}}$ & 15 & 34 & 31 & 80 \\
& Assumed proportion of renewables & 0.31 & 0.10 & 0.12 & 0.15 \\
& Renewable target $\left(\mathrm{kWh} \mathrm{p}^{-1} \mathrm{~d}^{-1}\right)$ & 4.6 & 3.4 & 3.7 & 11.7 \\
\hline
\end{tabular}

${ }^{\mathrm{a}}$ : Commercial electricity and heat use based on area of warehouses $\left(356500 \mathrm{~m}^{2}\right)$ and offices $\left(179400 \mathrm{~m}^{2}\right)$. Annual mean fossil fuel and electricity use in warehousing estimated as $133 \mathrm{kWh} \mathrm{m}^{-2}$ and $32 \mathrm{kWh} \mathrm{m}^{-2}$ respectively [12]. Annual mean fossil fuel and electricity use in offices (assumed double storey) at 138 $\mathrm{kWh} \mathrm{m}^{-2}$ and $177 \mathrm{kWh} \mathrm{m}^{-2}$ respectively [12].

${ }^{b}$ : Estimate of $35 \mathrm{GWh}$ for arable and grazing systems in the Marston Vale in 2009 was assumed to be split equally between electricity, transport and heat.

c: Total delivered energy consumption in the UK in 2009 was 154.3 million tonnes of oil equivalent. Assuming that one tonne of oil is equivalent to $11630 \mathrm{kWh}$ and that the population of the UK is 61.4 million [7], mean energy use is $80 \mathrm{kWh} \mathrm{p}^{-1} \mathrm{~d}^{-1}$. Of this 29.4 million tonnes of oil was used for electricity $\left(15 \mathrm{kWh} \mathrm{p}^{-1} \mathrm{~d}^{-1}\right), 64.9$ million tonnes was for transport $\left(34 \mathrm{kWh} \mathrm{p}^{-1} \mathrm{~d}^{-1}\right)$, and the difference was attributed to heat and other forms of energy $\left(31 \mathrm{kWh} \mathrm{p}^{-1} \mathrm{~d}^{-1}\right)$. 
Table 5. Estimate of food energy purchase by UK households (>7 years old) [15], and the derived estimates of the animal feed required using values from Williams et al. [13].

\begin{tabular}{|c|c|c|c|c|c|c|}
\hline Product & $\begin{array}{l}\text { Human } \\
\text { food energy } \\
\text { purchase } \\
\left(\mathrm{kWh} \mathrm{p}^{-1} \mathrm{~d}^{-1}\right)\end{array}$ & $\begin{array}{l}\text { Energy } \\
\text { density of } \\
\text { food } \\
\left(\mathrm{MJ} \mathrm{kg}^{-1}\right)\end{array}$ & $\begin{array}{l}\text { Grass } \\
\text { input/food } \\
\text { output } \\
\left(\mathrm{kg} \mathrm{kg}^{-1}\right)\end{array}$ & $\begin{array}{l}\text { Animal } \\
\text { grass } \\
\text { intake }^{\mathrm{a}} \\
\left(\mathrm{kWh} \mathrm{p}^{-1} \mathrm{~d}^{-1}\right)\end{array}$ & $\begin{array}{l}\text { Crop } \\
\text { input/grain } \\
\text { output } \\
\left(\mathrm{kg} \mathrm{kg}^{-1}\right)\end{array}$ & $\begin{array}{l}\text { Animal } \\
\text { crop } \\
\text { intake }^{\mathrm{b}} \\
\left(\mathrm{kWh} \mathrm{p}^{-1} \mathrm{~d}^{-1}\right)\end{array}$ \\
\hline Plant-products & 1.93 & & & & & \\
\hline Milk & 0.30 & 2.8 & 0.9 & 0.86 & 0.5 & 0.77 \\
\hline Poultry & 0.16 & 8.7 & & & 3.1 & 0.76 \\
\hline Pig meat & 0.08 & 9.2 & & & 4.4 & 0.54 \\
\hline Beef & 0.07 & 9.0 & 14.5 & 1.08 & 4.3 & 0.47 \\
\hline Lamb & 0.03 & 10.5 & 33.4 & 0.90 & 2.9 & 0.12 \\
\hline Eggs & 0.02 & 6.3 & & & 3.1 & 0.14 \\
\hline Fish & 0.04 & & & & & \\
\hline Animal-products & 0.72 & & & 2.84 & & 2.80 \\
\hline Total & 2.65 & & & & & \\
\hline
\end{tabular}


Table 6. Estimated potential energy production from solar photovoltaics (PV) in the Marston Vale.

\begin{tabular}{|c|c|c|c|c|c|c|c|}
\hline Energy source & Output & $\begin{array}{l}\text { Proper- } \\
\text { ties }\end{array}$ & $\begin{array}{l}\text { Mean } \\
\text { roof } \\
\text { area } \\
\left(\mathrm{m}^{2}\right)\end{array}$ & $\begin{array}{l}\text { Proportion } \\
\text { of roof } \\
\text { used }\end{array}$ & $\begin{array}{l}\text { Annual } \\
\text { yield } \\
\left(\mathrm{kWh} \mathrm{m}^{-2}\right)\end{array}$ & $\begin{array}{l}\text { Energy } \\
\text { (GWh) }\end{array}$ & $\begin{array}{l}\text { Energy } \\
\left(\mathrm{kWh} \mathrm{p}^{-1} \mathrm{~d}^{-}\right. \\
\left.{ }^{1}\right)^{\mathrm{a}}\end{array}$ \\
\hline Domestic PV & Electricity & 20682 & $98^{\mathrm{b}}$ & 0.125 & $117^{\mathrm{c}}$ & 29.6 & 1.6 \\
\hline $\begin{array}{l}\text { Existing } \\
\text { commercial PV }\end{array}$ & Electricity & $88^{\mathrm{d}}$ & $6092^{c}$ & 0.125 & $117^{\mathrm{c}}$ & 7.8 & 0.4 \\
\hline \multicolumn{8}{|c|}{${ }^{\mathrm{a}}$ Per capita values are based on a population of 49637.} \\
\hline \multirow{2}{*}{\multicolumn{8}{|c|}{$\begin{array}{l}\text { Typical areas per domestic houses in the ward areas of Great Barford, Marston and Eastcotts calculated } \\
\text { using Department of Communities and Local Government [22] values are about } 98 \mathrm{~m}^{2} \text {. Using an } \\
\text { eighth of the area means a mean panel size of } 12 \mathrm{~m}^{2} \text {. }\end{array}$}} \\
\hline & & & & & & & \\
\hline${ }^{\mathrm{d}}$ The plan area of & e 88 largest co & nmercial b & ildings in 2 & & lated from aeri & l photogra & \\
\hline
\end{tabular}

Table 7. Estimated potential energy production from wind turbines in the Marston Vale.

\begin{tabular}{|c|c|c|c|c|c|}
\hline Energy source & Output & $\begin{array}{l}\text { Number } \\
\text { of } \\
\text { turbines }\end{array}$ & $\begin{array}{l}\text { Annual energy } \\
\text { output per turbine } \\
(\mathrm{kWh})\end{array}$ & & $\begin{array}{l}\text { Energy }^{\mathrm{a}} \\
\left(\mathrm{kWh} \mathrm{p}^{-1} \mathrm{~d}^{-1}\right)\end{array}$ \\
\hline $\begin{array}{l}\text { Large wind turbine } \\
(2 \mathrm{MW})\end{array}$ & Electricity & $98^{b}$ & $3,897,000^{\mathrm{c}}$ & 381.9 & 21.1 \\
\hline $\begin{array}{l}\text { Domestic pole- } \\
\text { mounted }\end{array}$ & Electricity & $176^{\mathrm{d}}$ & $11578^{\mathrm{e}}$ & 2.0 & 0.1 \\
\hline \multicolumn{6}{|c|}{$\begin{array}{l}\text { a Per capita values are based on a population of } 49637 . \\
\text { Estimate of number of turbines assuming a buffer around all current and consented settlements ( } 800 \mathrm{~m} \\
\text { buffer), commercial areas ( } 500 \mathrm{~m} \text { ), and woodlands }(500 \mathrm{~m} \text { ) and excluding water bodies and areas where } \\
\text { the slope was greater than } 10 \% \text {. A minimum spacing of } 335 \mathrm{~m} \text { of five times a blade diameter of } 67 \mathrm{~m} \\
\text { was assumed) [24]. } \\
\text { C National Energy Foundation [25] quoted by ENTEC [26] estimated that an Enercon E70 (2 MW) wind } \\
\left.\text { turbine with a hub height of } 64 \mathrm{~m}^{-1} \text { would generate } 3,897,000 \mathrm{kWh} \text { per year (capacity factor of } 22 \%\right) \\
\text { assuming a wind speed of } 6.1 \mathrm{~m} \mathrm{~s}^{-1} \text {. } \\
\text { The Energy Savings Trust [27] recommends that wind turbines should only be located in areas where } \\
\text { the windspeed is at least } 5 \mathrm{~m} \mathrm{~s}^{-1} \text { using the MCS adjusted NOABL tool. Within the Marston Vale study } \\
\text { area, a wind speed of } 5 \mathrm{~m} \mathrm{~s}^{-1} \text { or more will only occur in rural areas [28]. The proportion of houses in } \\
\text { rural areas is assumed to be } 3.3 \% \text { [24] of the existing } 10656 \text { dwellings (351 houses). For the purposes } \\
\text { of this exercise it is assumed that half of the rural houses could use a pole-mounted turbine (176). } \\
\text { Annual mean output for a pole-mounted turbine (non-farm based) is } 11578 \mathrm{kWh} \text { [27]. }\end{array}$} \\
\hline
\end{tabular}


Table 8. Estimated potential energy production from solar heating panels and ground-source heat pumps in the Marston Vale.

\begin{tabular}{llllllll}
\hline Energy source & Output & $\begin{array}{l}\text { House- } \\
\text { holds }\end{array}$ & $\begin{array}{l}\text { Annual } \\
\text { water } \\
\text { heating } \\
\text { per } \\
\text { house } \\
(\mathrm{kWh})\end{array}$ & $\begin{array}{l}\text { Mean } \\
\text { floor } \\
\text { area per } \\
\text { house } \\
\left(\mathrm{m}^{2}\right)\end{array}$ & $\begin{array}{l}\text { Annual } \\
\text { mean } \\
\text { space } \\
\text { heating } \\
\left.(\mathrm{kWh} \mathrm{m})^{-2}\right)\end{array}$ & $\begin{array}{l}\text { Heating } \\
\text { require } \\
\text { ment } \\
(\mathrm{GWh})\end{array}$ & $\begin{array}{l}\text { Energy } \\
\left(\mathrm{kWh} \mathrm{p}^{-1} \mathrm{~d}^{-}\right.\end{array}$ \\
\hline $\begin{array}{l}\text { Domestic solar } \\
\text { heating panels }\end{array}$ & $\begin{array}{l}\text { Water } \\
\text { heating }\end{array}$ & 20692 & $1273^{\mathrm{b}}$ & & & 26.3 & 1.4 \\
\hline $\begin{array}{l}\text { Ground source } \\
\text { heat pumps }\end{array}$ & $\begin{array}{l}\text { Space } \\
\text { heating } \\
\text { Electricity }\end{array}$ & 10036 & & $91.2^{\mathrm{c}}$ & $128.5^{\mathrm{c}}$ & 117.8 & 6.5 \\
\hline
\end{tabular}

${ }^{\mathrm{a}}$ Per capita values are based on a population of 49637.

${ }^{\mathrm{b}}$ Mean level of domestic hot water heating is $16.8 \mathrm{MJ} \mathrm{d}^{-1}$ [28], or $1703 \mathrm{kWh}$ per year. In July the mean hot water user per household is 100 litres and the average temperature rise is $30^{\circ} \mathrm{C}$ [29], so assuming a specific heat capacity of water of $4.2 \mathrm{~kJ} \mathrm{~kg} \mathrm{k}^{-1} \mathrm{~K}^{-1}$, the annual water heating per house would be 1273 $\mathrm{kWh}$. As a collector can capture about $500 \mathrm{kWh} \mathrm{m}^{-2} \mathrm{a}^{-1}$ [30], this would require $2.5 \mathrm{~m}^{2}$ of collector.

${ }^{c}$ Mean space heating required for a GB house in $2006=11716 \mathrm{kWh}$ [31], and mean total usable floor area of a dwelling in England in 2008 was $91.2 \mathrm{~m}^{2}$ [32], therefore average annual space heating requirement is $128.5 \mathrm{kWh} \mathrm{m}^{-2}$. However it is assumed that a ground-source heat pump has an output of 3.5 units of heat for 1 unit of electrical input [30].

Table 9. Estimated potential energy production from municipal waste in the Marston Vale.

\begin{tabular}{llllcc}
\hline Source & Output & $\begin{array}{l}\text { Quantity of } \\
\text { waste } \\
(\mathrm{t} / \text { person/year })\end{array}$ & $\begin{array}{l}\text { Output } \\
(\mathrm{kWh} / \mathrm{t})\end{array}$ & $\begin{array}{l}\text { Energy } \\
(\mathrm{GWh})\end{array}$ & $\begin{array}{l}\text { Energy } \\
\left(\mathrm{kWh} \mathrm{p}^{-1} \mathrm{~d}^{-1}\right)^{\mathrm{a}}\end{array}$ \\
\hline Municipal & Electricity & $0.53^{\mathrm{b}}$ & $735^{\mathrm{c}}$ & 19.4 & 1.1 \\
waste & Heat & 0.53 & $402^{\mathrm{d}}$ & 10.5 & 0.6 \\
\hline
\end{tabular}

${ }^{\mathrm{a}}$ Per capita values are based on a population of 49637.

b. Central Bedfordshire produces 136000 tonnes of waste from 255000 people

c. Covanta Energy Ltd [33]

d. This is below the potential, but is considered usable [33].

Table 10. Electricity production in the Marston Vale from landfill gas for 2009-10 [34]

\begin{tabular}{llrcrc}
\hline Output & Site & $\begin{array}{l}\text { Area } \\
(\mathrm{ha})\end{array}$ & $\begin{array}{l}\text { Electricity } \\
\text { capacity }(\mathrm{MW})\end{array}$ & $\begin{array}{l}\text { Energy } \\
(\mathrm{GWh})\end{array}$ & $\begin{array}{l}\text { Energy } \\
\left(\mathrm{kWh} \mathrm{p}^{-1} \mathrm{~d}^{-1}\right)^{\mathrm{a}}\end{array}$ \\
\hline Electricity & Brogborough & 125 & 28.7 & 191.0 & \\
& Stewartby & 78 & 12.5 & 58.0 & \\
& Elstow & 32 & 1.8 & 4.6 & \\
\hline & Sub-total & 261 & 43.0 & 253.6 & 14.0 \\
\hline
\end{tabular}

${ }^{\mathrm{a}}$ Per capita values are based on a population of 49637 . 
Table 11. Summary of the mean yield of biomass crops and the energy yield for food, feed, wood, heat, electricity and fuel assuming current land use, and if all the agricultural area (10750 ha) was allocated to that crop. Per capita values assume 49637 people.

\begin{tabular}{|c|c|c|c|c|c|c|c|c|c|c|}
\hline $\begin{array}{l}\text { Crop and } \\
\text { current area }\end{array}$ & $\begin{array}{l}\text { Component } \\
\text { and moisture content } \\
\text { (wet basis) }\end{array}$ & $\begin{array}{l}\text { Yield } \\
\text { dry } \\
\left(\mathrm{t} \mathrm{ha}^{-1}\right) \\
\end{array}$ & $\begin{array}{l}\text { Yield } \\
\text { wet } \\
\left(\mathrm{t} \mathrm{ha}^{-1}\right) \\
\end{array}$ & $\begin{array}{l}\text { Harvested } \\
\text { proportion }\end{array}$ & Use & $\begin{array}{l}\text { Energy } \\
\text { yield } \\
\left(\mathrm{MJ} \mathrm{kg}^{-1}\right)^{\mathrm{a}} \\
\end{array}$ & $\begin{array}{l}\text { Efficie } \\
\text { ncy }\end{array}$ & $\begin{array}{l}\text { Energy } \\
\text { yield } \\
\left(\mathrm{kWh} \mathrm{ha}^{-1}\right) \\
\end{array}$ & $\begin{array}{l}\text { Energy on } \\
\text { current area } \\
\left(\mathrm{kWh} \mathrm{p}^{-1} \mathrm{~d}^{-1}\right) \\
\end{array}$ & $\begin{array}{l}\text { Energy on } \\
10750 \text { ha } \\
\left(\mathrm{kWh} \mathrm{p}^{-1} \mathrm{~d}^{-1}\right) \\
\end{array}$ \\
\hline \multirow{6}{*}{$\begin{array}{l}\text { Wheat } \\
\text { (4141 ha) }\end{array}$} & Grain $(16 \%)$ & 8.20 & 9.76 & 1.00 & Food & $13.3^{b}$ & 1.0 & 36000 & 8.2 & 21.4 \\
\hline & & & & 1.00 & or Heat & $13.9^{c}$ & 0.8 & 30100 & 6.9 & 17.9 \\
\hline & Ethanol $(0 \%)$ & & & 0.29 & or Fuel and & $26.7^{\mathrm{d}}$ & 1.0 & 20900 & 4.8 & 12.4 \\
\hline & Distiller grains $(10 \%)$ & & & 0.47 & Feed & $14.4^{\mathrm{f}}$ & 1.0 & 18300 & 4.2 & 10.9 \\
\hline & Straw $(15 \%)$ & 6.24 & 7.34 & 0.65 & Feed & $4.8^{\mathrm{e}}$ & 1.0 & 6300 & 1.4 & 3.7 \\
\hline & & & & & or Heat & $14.3^{c}$ & 0.8 & 15100 & 3.5 & 9.0 \\
\hline \multirow{3}{*}{$\begin{array}{l}\text { Barley } \\
\text { (456 ha) }\end{array}$} & Grain $(16 \%)$ & 6.29 & 7.49 & 1.00 & Feed & $12.4^{\mathrm{a}}$ & 1.0 & 25700 & 0.6 & 15.3 \\
\hline & Straw $(15 \%)$ & 7.38 & 8.68 & 0.65 & Feed & $6.2^{\mathrm{e}}$ & 1.0 & 9700 & 0.2 & 5.8 \\
\hline & & & & & Heat & $14.5^{\mathrm{c}}$ & 0.8 & 18100 & 0.5 & 10.7 \\
\hline \multirow{6}{*}{$\begin{array}{l}\text { Oilseed } \\
\text { (1481 ha) }\end{array}$} & Rapeseed (15\%) & 3.33 & 3.92 & 1.00 & & & & & & \\
\hline & Rapeseed oil (0\%) & & & 0.37 & Food & $37.2^{\mathrm{d}}$ & 1.0 & 14900 & 1.2 & 8.8 \\
\hline & & & & 0.35 & Biodiesel & $37.2^{\mathrm{d}}$ & 1.0 & 14100 & 1.2 & 8.4 \\
\hline & Rapemeal (15\%) & & & 0.55 & Feed & $10.1^{\mathrm{a}}$ & 1.0 & 6000 & 0.5 & 3.6 \\
\hline & & & & 0.55 & or Heat & $14.1^{\mathrm{d}}$ & 0.8 & 6700 & 0.5 & 4.0 \\
\hline & Straw $(15 \%)$ & 5.50 & 5.88 & 0.65 & Heat & $14.2^{c}$ & 0.8 & 12000 & 1.0 & 7.1 \\
\hline \multirow{2}{*}{$\begin{array}{l}\text { Spring crop } \\
\text { (1099 ha) }\end{array}$} & Pulse (12\%) & 3.49 & 3.97 & 1.00 & Feed & $13.8^{\mathrm{a}}$ & 1.0 & 15100 & 0.9 & 9.0 \\
\hline & Straw $(15 \%)$ & 6.48 & 7.62 & 0.65 & Heat & $14.2^{\mathrm{c}}$ & 0.8 & 15600 & 0.9 & 9.3 \\
\hline \multirow{2}{*}{$\begin{array}{l}\text { Grass } \\
(2598 \text { ha })\end{array}$} & Grass (15\%) & 7.14 & 8.40 & 0.65 & Feed & $9.0^{\mathrm{e}}$ & 1.0 & 13600 & 2.0 & 8.1 \\
\hline & & & & & or Heat & $14.4^{\mathrm{c}}$ & 0.8 & 17500 & 2.5 & 10.4 \\
\hline \multirow{3}{*}{$\begin{array}{l}\text { Hardwood } \\
\text { (1281 ha) }\end{array}$} & Timber $(30 \%)$ & 3.62 & 5.17 & 0.70 & Timber & $12.1^{\mathrm{c}}$ & 1.0 & 12200 & 0.9 & 7.2 \\
\hline & & & & & or Heat & & 0.8 & 9700 & 0.7 & 5.8 \\
\hline & Branches $(30 \%)$ & 2.96 & 4.23 & 0.70 & Heat & $12.1^{\mathrm{c}}$ & 0.8 & 7900 & 0.6 & 4.7 \\
\hline \multirow{2}{*}{$\begin{array}{l}\text { Willow } \\
(0 \text { ha) }\end{array}$} & Chips (30\%) & 8.16 & 11.66 & 1.00 & Heat & $12.1^{\mathrm{c}}$ & 0.8 & 31400 & 0.0 & 18.6 \\
\hline & & & & & or Electricity & & 0.3 & 11800 & 0.0 & 7.0 \\
\hline \multirow{2}{*}{$\begin{array}{l}\text { Miscanthus } \\
(0 \mathrm{ha})\end{array}$} & Bale (25\%) & 9.71 & 12.95 & 0.83 & Heat & $12.6^{c}$ & 0.8 & 30000 & 0.0 & 17.9 \\
\hline & & & & & or Electricity & & 0.3 & 11200 & 0.0 & 6.6 \\
\hline \multirow{3}{*}{$\begin{array}{l}\text { Softwood } \\
(0 \text { ha })\end{array}$} & Timber $(30 \%)$ & 5.77 & 8.24 & 0.70 & Timber & $12.4^{\mathrm{c}}$ & 1.0 & 19900 & 0.0 & 11.9 \\
\hline & & & & & or Heat & & 0.8 & 15900 & 0.0 & 9.4 \\
\hline & Branches $(30 \%)$ & 1.20 & 1.71 & 0.70 & Heat & $12.4^{\mathrm{c}}$ & 0.8 & 3300 & 0.0 & 2.0 \\
\hline
\end{tabular}

Notes: ${ }^{\mathrm{a}}$ :Energy yields are based on the indicated moisture content ${ }^{\mathrm{b}}$ : Metabolisable energy as described by Noblet et al. [41], ${ }^{\mathrm{c}}$ : Kaltschmitt et al. [21];

d: Fehrenbach et al. [42]; ${ }^{\mathrm{e}}$ McDonald et al [43]: metabolisable energy for a ruminant, corrected for moisture content; ${ }^{\mathrm{f}}$ :Bonnardeaux [44]. 
Table 12. Description of the three energy scenarios

\begin{tabular}{ll}
\hline Scenario & Description \\
\hline 1. & $\begin{array}{l}\text { Default position: use current cropping pattern and no bio-energy production, } \\
\text { but described potential levels of other forms of renewable energy. }\end{array}$ \\
2. & $\begin{array}{l}\text { Use current cropping pattern, but use all food crops to provide heat and fuel, } \\
\text { once demand for human food (but not animal feed) is met. The non-timber } \\
\text { branchwood from woodland would also be used for heat. }\end{array}$ \\
& $\begin{array}{l}\text { Planting the whole arable and grassland area to wheat, and using that to } \\
\text { generate heat and transport fuel, once the demand for human food (but not } \\
\text { animal feed) is met. Branchwood is again used for heat. }\end{array}$ \\
\hline
\end{tabular}

Table 13. Effects of three scenarios on the supply of electricity, transport fuel, heat, food, feed and wood $\left(\mathrm{kWh} \mathrm{p}^{-1} \mathrm{~d}^{-1}\right)$.

\begin{tabular}{|c|c|c|c|c|c|c|}
\hline Form of & Total & Renewabl & & & Scenario & \\
\hline demand & $\begin{array}{c}\text { deman } \\
\mathrm{d}\end{array}$ & Targets & $\begin{array}{l}\text { 1a. No } \\
\text { biomass } \\
\text { renewable } \\
\text { s } \\
+7 \text { wind } \\
\text { turbines }\end{array}$ & $\begin{array}{l}\text { 1b. No } \\
\text { biomass } \\
\text { renewable } \\
\text { s } \\
+98 \text { wind } \\
\text { turbines }\end{array}$ & $\begin{array}{l}\text { 2. Current } \\
\text { cropping } \\
\text { with } \\
\text { renewable } \\
\text { s }\end{array}$ & $\begin{array}{l}\text { 3.Monocultur } \\
\mathrm{e} \\
\text { wheat with } \\
\text { renewables }\end{array}$ \\
\hline Electricit & 15.0 & 4.6 & 4.7 & 24.3 & 24.3 & 24.3 \\
\hline $\begin{array}{l}\text { y } \\
\text { Transport }\end{array}$ & 34.0 & 3.4 & 0.0 & 0.0 & 4.9 & 11.4 \\
\hline Heat & 31.0 & 3.7 & 6.1 & 6.1 & 12.6 & 15.7 \\
\hline Food & 1.9 & & 9.4 & 9.4 & 1.9 & 1.9 \\
\hline Feed & 5.6 & & 4.2 & 4.2 & 7.2 & 9.9 \\
\hline Wood & 4.4 & & 0.9 & 0.9 & 0.9 & 0.9 \\
\hline
\end{tabular}

